\title{
The impact of real exchange rates adjustments on global imbalances: a multilateral approach ${ }^{1}$
}

\author{
Jean-Pierre Allegret ${ }^{2}$, Audrey Sallenave ${ }^{3}$
}

\begin{abstract}
An extensive literature stresses that currency misalignments are costly in terms of growth performance. However, these studies do not consider the direct and indirect effects of currenciesí misalignments on other countries. In this paper, we analyze how misalignments of the dollar, the euro, and the renminbi affect their respective economies and those of their trading partners using a multi-country dataset GVAR model. Our model includes 15 advanced and emerging countries and uses quarterly data spanning the period 19802010. We find that misalignments significantly influence the world economy. We show that overvaluation and undervaluation shocks do not produce the same effects.
\end{abstract}

Keywords: GVAR, Misalignments, Growth

JEL Codes: F31, F41, F43

\section{Introduction}

Since the adoption of floating exchange rates by the major currencies in the 1970s', wide exchange rate fluctuations became a key issue for the stability of the world economy. Indeed, as stressed, among others, by Williamson (1983) and Isard et al. (2001), currency misalignments are costly. For instance, an overvaluation tends to undermine countries' competitiveness -and, then, growth performance- and may generate protectionnist pressures in countries with sizeable current account deficits. At the beginning of the 1980s', the strong U.S. dollar appreciation in both nominal and real terms spawned intense debates on the so-called yen undervaluation (see Funabashi, 1988). Since the 1990s', the renminbi-U.S. dollar exchange rate is at the center of the debates relative to exchange rate policies. An extensive literature stresses that exchange rates misalignments and global imbalances have close relationships (Brender and Pisany, 2010; Blanchard and Milesi-Ferretti, 2011). More recently, the deep economic damages caused by the subprime crises have increased the probability of a currency war among industrialized countries on the one hand, and between these latter and emerging countries on the other hand ${ }_{4}^{4}$ Cline and Williamson (2010) show that more and more countries -for instance Brazil, China, Japan, Korea, Singapore, and Switzerland- use foreign exchange interventions and-or capital controls to contain currency appreciation.

Exchange rate policies are issues that are multilateral by nature. Indeed, a weaker exchange rate in a specific country implies stronger ones for some other economies. The IMF has recognized this multilateral dimension by establishing in 1995 the Coordinating Group on Exchange Rate Issues (CGER, see Isard et al., 2001). The main purpose of the CGER is to offer a methodology identifying currency misalignments and solutions to correct them in a multilateral framework 5 From this standpoint, coordinated exchange rate realignments are a major issue for the stability of the international monetary system (Angeloni et al., 2011).

\footnotetext{
${ }^{1}$ We are grateful to Valerie Mignon for invaluable comments and encouragement. We also wish to thank Vanessa Smith and Ron Smith for many useful discussion on the GVAR methodology and the anonymous referee for his helpful remarks and suggestions.

${ }^{2}$ EconomiX, UMR 7235 University of Paris Ouest Nanterre La Défense, France. jallegret@u-paris10.fr

${ }^{3}$ LEAD, UFR Sciences Economiques et Gestion, University of Sud Toulon-Var, France. audrey.sallenave@univ-tln.fr

${ }^{4}$ According to Cline and Williamson (2010), the term currency war has been introduced by the finance minister of Brazil, Guido Mantega. This latter has asked the IMF to develop an index measuring whether a currency is held artificially low or not. In other words, he envisaged that the IMF produces information on currency manipulation by members countries.

${ }^{5}$ Eight years ago, Williamson and Miller (1987) developed a blueprint for exchange rate stability in a multilateral framework.
} 
In addition, a recent literature has demonstrated the role of exchange rates in economic growth models (Rapetti 2013; Arslan et al., 2012) ${ }^{6}$ Some empirical studies -for instance Rodrik (2008), Eichengreen (2008) and Sallenave (2009)- have shown that undervalued exchange rates favor economic growth. In a similar vein, Skott et al. (2012) have built a theoretical two-sector equilibrium model to establish a positive association between economic development and an accommodating exchange rate policy coupled with an investment promotion.

If a large part of the literature highlights benefits (detriments) of undervalued (overvalued) currencies, it does not consider the direct and indirect effects of currencies' misalignments on the economic performances of other countries $\mathbf{7}^{7}$ Currency misalignments affect current accounts through several channels: the financial channel (in particular the valuation effect), the channel of savings and investment, and the competitiveness channel.In this paper, we analyze how undervaluation (overvaluation) of the dollar, the euro, and the renminbi affect their respective economies and those of some of their trading partners using a multi-country dataset GVAR ${ }^{8}$ model. Thus, we focus our attention on the competitiveness channel. GVAR modelling has become a very useful econometric tool these last years. After Pesaran et al. (2004)'s introduction of the global VAR, several papers have analyzed the macroeconomic or financial interdependencies in this specific way. As a multicountry framework, it is particularly adapted to assess spillover effects in the aftermath of a historical slowdown in U.S. equity prices (Galesi and Sherri, 2009). Hiebert and Vanteenkiste (2007) examine for 12 manufacturing industries over the 1977-2003 period the response of U.S. manufacturing labour market variables to various shocks, including trade openness and technology. Dees and Saint-Guilhem (2011) estimate a GVAR model to assess the role of the United States as an engine of global economy growth. They stress the evolving influence of this country on the world economy across time. They show that, if the direct influence of the U.S. economy has declined, it remains significant through the third market effect.

Our paper is related to the GVAR models that built a global trade flows framework (see Dees et al., 2007a; Greenwood-Nimmo et al., 2012; and Bussière et al., 2012) to analyze the dynamics of global trade flows and global imbalances. Our model includes 15 countries accounting for more than $70 \%$ of the world exports, and aims at shedding some light on the international transmission of exchange rate misalignments. Our sample countries include both advanced and emerging economies in order to better consider interdependencies across countries. In addition, we use quarterly data spanning the period 1980-2010. Contrary to the traditional literature (Pesaran et al., 2004; Pesaran and Smith, 2006), we consider deviation levels of each of our three key currencies with respect to their equilibrium level estimated with the BEER approach. Two distinct indexes are then calculated in order to disentangle clearly periods of overvaluation from undervaluation ones. Relative to the previous literature that considers phases of appreciation and depreciation of the real exchange rate, we offer a more accurate analysis of the effects of misalignments on macroeconomic variables. As GVAR models are linear, the use of two sub-indices of misalignments allows us to avoid the symmetric effects of currency overvaluation-undervaluation due to this linearity property. Indeed, we consider that there is no reason to assume that shocks to exchange rate overvaluation and undervaluation lead to rigourously similar (but with opposite signs) effects in terms of size.

This paper contributes to three strands of literature. First, considering the literature on the effects of misalignments on economic growth, it suggests that it is very important to integrate in the analysis interdepencies. Indeed, we find that misalignments of the three key currencies significantly influence the world economy. Second, the paper sheds some lights on the debate concerning the asymmetric effects of exchange rate changes (Chinn and Wei, 2013). Indeed, we show that overvaluation shocks and undervaluation shocks do not produce the same effects in terms of size. Finally, by disentangling between overvaluation and undervaluation shocks, we contribute to the recent literature on the contribution of the exchange rate to the reduction of current account deficits (Chiu et al, 2010; Kappler et al, 2013).

The rest of this paper is organized as follows. In the next section we describe the GVAR model. In

\footnotetext{
${ }^{6}$ See Aguirre and Calderon (2005); Berg and Miao (2010).

${ }^{7}$ An exception is the paper by Mattoo et al. (2012). Using disaggregated trade data for 124 developing exporters and 57 large importers over the period 2000-2008, they find that changes in the renminbi exchange rate have significant spillover effects. For instance, a $10 \%$ appreciation of the Chinese currency increases a developing country's exports by 1.5 to $2 \%$ on average.

${ }^{8}$ Global Vector Autoregressive Modelling.
} 
section 3 we discuss its estimation. Section 4 is devoted to the derivation of our index of undervaluation and overvaluation. Sections 5 and 6 report respectively the results from the generalized impulse response functions and the generalized forecast error variance. Section 7 concludes.

\section{The Global VAR theoretical framework}

\subsection{Individuals' country-specific models}

Consider a set of $N$ countries, with country 0 denoting the reference one. Following the notations of Pesaran et al. (2004), we confine our exposition to a first order dynamic specification represented by a $\operatorname{VARX^{*}}(1,1)$

$$
x_{i t}=a_{i 0}+a_{i 1} t+\Phi_{i} x_{i, t-1}+\Lambda_{i 0} x_{i t}^{*}+\Lambda_{i 1} x_{i, t-1}^{*}+\mu_{i t}
$$

where $t=1,2, \ldots, T, i=1,2, \ldots, N, x_{i, t}$ is a $k_{i} \times 1$ vector containing country specific variables, $x_{i, t}^{*}$ is a $k_{i}^{*} \times 1$ vector of foreign variables. $\Lambda_{i 0}$ and $\Lambda_{i 1}$ are $k_{i} \times k_{i}^{*}$ matrices of coefficients related to respectively, contemporaneous and lagged foreign variables. The vector of fixed intercepts $a_{i 0}$ is a $k_{i} \times 1$ and $a_{i 1}$ is a $k_{i} \times 1$ vector of coefficients of the deterministic time trend. The $k_{i} \times 1$ vector of idiosyncratic country specific shocks is given by $\mu_{i t}$ and is assumed to be serially uncorrelated with zero mean and non singular covariance matrix:

$$
\mu_{i t} \sim \text { i.i.d. }\left(0, \Sigma_{i i}\right)
$$

where $\sigma_{i i, l s}=\operatorname{cov}\left(\mu_{i l t}, \mu_{i l s}\right)$ and

$$
\Sigma_{i i}=\sigma_{i i, l s}
$$

where $i$ is the country index, $l$ and $s$ are variables belonging to this country $i$. We also allow $\mu_{i t}$ to be correlated across regions to a limited degree.

Foreign variables are constructed using trade weights that reflect the specific geographical trade composition of each country. The choice of trade weights rests on the fact that bilateral trade exerts a strong influence on inter-country business cycle linkages (See, among others, Forbes and Rigobon (2004), Imbs (2004), and Baxter and Kouparitsas (2005). The construction of foreign variables is as follows:

$$
x_{i t}^{*}=\sum_{j=1}^{N} w_{i j} x_{j t}
$$

where

$$
\sum_{j=1}^{N} w_{i j}=1
$$

for all $i, j=1, \ldots, N$ and $w_{i i}=0$ for all $i=1, \ldots, N$. Here, we use time varying weights that cover the entire period.

\subsection{Transition to the Global VAR}

As there is contemporaneous dependence of the domestic variables $x_{i t}$ on the foreign variables $x_{i t}^{*}$, (1) need to be solved simultaneously for all the domestic variables, $x_{i t}$ for $i=0,1, \ldots, N$.

\footnotetext{
${ }^{9}$ The GVAR model comprises country-specific $V A R X^{*}$ models that relate the core variables of each economy to their foreign counterparts. Each of them are then combined to form the GVAR model.

Lag orders $p_{i}$ and $q_{i}$ of respectively domestic and foreign variables are selected using the Akaike information criterion, which corresponds to the maximised value of the log-likelihood function $\hat{\Sigma}_{i}=\hat{\epsilon_{i t}} \hat{\epsilon}_{i t}^{\prime}$ computed according to the residuals $\hat{\epsilon}_{i t}$ obtained from the estimation of the individual VARX models given by 1. Table for the lag order $p_{i}$ and $q_{i}$ are available upon request. We allow lags up to four. The lag order of the foreign variables $q_{i}$ is found to be equal to one in all countries and two for domestic variables $p_{i}$. The order in the GVAR in what follows is thus a $\operatorname{VARX}(2,1)$ for both $G V A R_{\text {under }}$ and $G V A R_{\text {over }}$.

Table displaying the number of cointegration relationship based on the trace test is also available upon request.

We used the 95\% MacKinnon's critical value model and do not impose ad hoc adjustments in the number of cointegration relations and consider the exact number of cointegration relationships.
} 
We can now rewritte (1) as follows:

$$
A_{i} z_{i t}=a_{i 0}+a_{i 1} t+B_{i} z_{i, t-1}+\mu_{i t}
$$

where $A_{i}=\left(I_{k i}-\Lambda_{i 0}\right), B_{i}=\left(\phi_{i}, \Lambda_{i t}\right)$ where the dimensions of $\Lambda_{i}$ and $B_{i}$ are $k_{i} *\left(k_{i}+k_{i}^{*}\right)$ and $A_{i}$ has a full rank i-e rank $\left(A_{i}=k_{i}\right)$. Each endogenous domestic variable of all countries is stacked in a $k \times 1$ global vector denoted by $x_{t}=\left(x_{1}, x_{2 t}, \ldots x_{N, t}\right)^{\prime}$ where $k$ is the sum of the endogenous variables contained in the model i-e $k=\sum_{i=1}^{N} k_{i}$.

Then, we can write:

$$
z_{i, t}=W_{i} X_{t}
$$

where $W_{i}$ is a weighting matrix of dimension $\left(k_{i}+k_{i}^{*}\right) \times k$ i-e $W_{i}$ is the country specific link matrix that allows to link the country specific model in a global VAR one. Then, each country model can be written in terms of the global vector $x_{t}$. Using (6) in (7):

$$
A_{i} W_{i} x_{i t}=a_{i 0}+a_{i 1} t+B_{i} W_{i} x_{i, t-1}+\mu_{i t}
$$

where $A_{i} W_{i}$ and $B_{i 1} W_{i}$ are both $k_{i} \times k$ matrix. Then, a $\operatorname{GVAR}(1,1)$ model can now be written as:

$$
G x_{t}=a_{0}+a_{1} t+H x_{t-1}+\mu_{t}
$$

where $a_{0}=\left[\begin{array}{c}a_{00} \\ a_{10} \\ \vdots \\ a_{N 0}\end{array}\right], a_{1}=\left[\begin{array}{c}a_{01} \\ a_{11} \\ \vdots \\ a_{N 1}\end{array}\right], \mu_{t}=\left[\begin{array}{c}\mu_{0 t} \\ \mu_{1 t} \\ \vdots \\ \mu_{N t}\end{array}\right], G=\left[\begin{array}{c}A_{0} W_{0} \\ A_{1} W_{1} \\ \vdots \\ A_{N} W_{N}\end{array}\right], H=\left[\begin{array}{c}B_{0} W_{0} \\ B_{1} W_{1} \\ \vdots \\ B_{N} W_{N}\end{array}\right]$

Following the assumption that $G$ is a $k \times k$ non singular matrix we can deduce the GVAR model in its reduced form:

$$
x_{t}=b_{0}+b_{1} t+F x_{t-1}+v_{t}
$$

where $F=G^{-1} H, b_{0}=G^{-1} a_{0}, b_{1}=G^{-1} a_{1}$ and $v_{t}=G^{-1} \mu_{t}$

At this step, the GVAR model can be recursively solved so as to predict future values of $x_{t}$. The analytical resolution is given by Pesaran et al. (2004).

\section{Estimation methodology}

\subsection{Data}

Our datase ${ }^{10}$ covers a time span period of 20 years, from 1980Q1 to 2010Q1 and encompasses the following countries: Australia, Brazil, Canada, China, the Euro area, Japan, Korea, Mexico, New Zealand, Norway, Sweden, Switzerland, Singapore, the United Kingdom, and the United States. Our country-specific $V A R X^{*}$ models include five variables and a global variable given by the oil price.

More specifically the country specific vector of domestic variables is:

$$
x_{i t}=\left(y_{i t}, \text { mis }_{i t}, \text { ex }_{i t}, \text { im }_{i t}, \text { inf }_{i t}, \text { oil }_{0 t}\right)^{\prime}
$$

for $\mathrm{i} \in\{0, \ldots, N\}$. The real output $y_{i t}$ is measured by the gross domestic product, $m i s_{i t}$ are the misalignments, given respectively by the overvaluation and undervaluation series 11 Misalignments series, displayed in Figure 1, are calculated using the BEER approach following the specification of Alberola et al. (1999,

\footnotetext{
${ }^{10}$ Data sources are given in Appendix A .

${ }^{11}$ See subsection 4.1.
} 
$2002 \sqrt{12}$ using quarterly data.

$e x_{i t}$ and $i m_{i t}$ respectively denote the volume of exports and imports 13 and inf $f_{i t}$ is the inflation rate. We follow Dees et al. (2007b), as we include the oil price as an endogenous variable in the U.S. model. The endogeneity of oil prices reflects the dominant role of the United States in the world economy.The U.S. model is set for $i=0$, we have:

$$
x_{0 t}=\left(y_{0 t}, \text { mis }_{0 t}, e x_{0 t}, \operatorname{im}_{0 t}, \text { inf }_{0 t}, o i l_{0 t}\right)^{\prime}
$$

where $o i l_{0 t}$ is the oil price index (in logarithm). The foreign counterpart of these vectors of variables are respectively given by:

$$
x_{i t}^{*}=\left(y_{i t}^{*}, m i s_{i t}^{*}, e x_{i t}^{*}, i m_{i t}^{*}, i n f_{i t}^{*}, o i l_{0 t}^{*}\right)^{\prime}
$$

for $i \in\{1, \ldots, N-1\}$, and

$$
x_{0 t}^{*}=\left(y_{0 t}^{*}, m i s_{0 t}^{*}, o i l_{0 t}, e x_{0 t}^{*}, i m_{0 t}^{*}, i n f_{0 t}^{*}\right)^{\prime}
$$

As we stated above, foreign variables are constructed using trade-weights. More specifically, we use timevarying trade shares of foreign countries in total exports and imports across the whole period.

Indeed, over our studied period, the geographical structure of international trade has changed. More precisely, two groups of countries can be distinguished. In the first, the share of developing Asia has increased since 1990 to the detriment of advanced countries. Both imports and exports are concerned by this change. Australia, Brazil, Japan, Korea, Singapore, and the United States belong to this group. China explains the main part of this new geography of trade flows. For instance, in primary commodity exporters -such as Australia and Brazil- the share of China in exports has dramatically increased since 1990. For Asian countries, Japan, Korea, and to a lesser extent Singapore, the rising share of China rests on the production integration process in East Asia in the context of the global production sharing (Haltmaier et al., 2007; Allegret and Essaadi, 2011). In the second group of countries -e.g. Canada, China, the Euro area, Mexico, New-Zealand, Norway, Sweden, Switzerland, and the United Kingdom- advanced countries still stand for more than 65 percent of trade flows. The Euro area exerts a striking influence on trade flows in other European countries (Norway, Sweden, Switzerland, and the United Kingdom) while the United States are critical for Canada and Mexico.

Two sets of GVAR ${ }^{14}$ are estimated ${ }^{15}$. The first one, namely $G V A R_{\text {under }}$, encompasses our measure of undervaluation index and the second one, $G V A R_{\text {over }}$, is estimated replacing $m i s_{i t}$ by the overvaluation index. We also include dummy variables to take into account currency and banking crises. ${ }^{16}$

\footnotetext{
${ }^{12}$ See section 4.

${ }^{13}$ Both series are taken in logarithm, deflated and adjusted from seasonal effects.

${ }^{14}$ Complete results of the GVAR estimation are available upon request to the authors.

${ }^{15}$ One of the main assumption underlying the GVAR states that foreign and global variables are considered as weakly exogeneous. In a cointegration framework, it implies that there is no long term feedback of $x_{i t}^{*}$ to $x_{i t}$. Here, we follow the methodology of Harbo et al. (1998), according to whom we test the joint significativity of the error correction terms in auxiliary equations for the country specific foreign variables $x_{i t}^{*}$. Formally, for each $l^{\text {th }}$ element of $x_{i t}^{*}$ the following regression is carried out:
}

$$
\Delta x_{i t, l}^{*}=a_{i l}+\sum_{j=1}^{r_{i}} \zeta_{i j, l} E \hat{C} M_{i j, t-1}+\sum_{k=1}^{s_{i}} \phi_{i k, l i, t-k}^{\prime}+\sum_{m=1}^{n_{i}} \Delta \psi_{i m, l}^{\prime} \Delta \tilde{x}_{i, t-m}^{*}+\eta_{i t, l}
$$

where $E \hat{C} M_{i j, t-1}, j=1,2, \ldots, r_{i}$ are the estimated error correction terms corresponding to the $r_{i}$ cointegration relations found for the $i^{\text {th }}$ country model, and $s_{i}$ and $n_{i}$ are the lag orders of the lagged changes for the domestic and foreign variables respectively. Then the test for weak exogeneity is an $F$ test on the joint null hypothesis that $\zeta_{i j, l}=0, j=1,2, \ldots, r_{i}$ in the above regression.

The weak exogeneity test for both estimated GVAR models is available upon request. The weak exogeneity hypothesis is only rejected for 9 of the 178 foreign variables.

Persistence profile, that provide information on the speed with which the cointegrating relationships return to their equilibrium states, are also available upon request. We find that both $G V A R_{\text {under }}$ and $G V A R_{\text {over }}$ models return to their equilibrium within 10 years, and, for most of them, prior to 6 years.

${ }^{16}$ We used the dataset of currency and banking crises of C.M. Reinhart: Crashes (Varieties). Dates for Banking Crises, Currency Crashes, Sovereign Domestic or External Default (or Restructuring), Inflation Crises, and Stock Market Crashes (Varieties). 


\section{Derivation of currency misalignments: the BEER framework}

We rely on the BEER approach introduced by Clark and MacDonald (1998), and more specifically on the stock-flow model developed by Alberola et al. $(1999,2002)$, where the real exchange rate is jointly determined by external balance as well as internal balance. The real exchange rate $q$ is defined as the relative price of domestic goods. With $p^{*}$ denoting the foreign price index and $p$ the domestic one, and $s$ standing for the nominal exchange rate defined as the price of foreign currency in terms of domestic currency, all variables being in logarithms, we have:

$$
q=s-p^{*}+p
$$

With ${ }^{17} \alpha$ the share of tradable goods in the price index, $p^{T}$ the price level of tradable goods, and $p^{N T}$ the price level of nontradable goods, the real exchange rate can also be written as follows ${ }^{18}$.

$$
q=\underbrace{\left(p^{T}-\left(s+p^{T *}\right)\right.}_{q^{T}}+\underbrace{\left[\alpha\left(p^{N T}-p^{T}\right)-\alpha^{*}\left(p^{N T *}-p^{T *}\right)\right]}_{q^{N T}}
$$

There are two sources of systematic movements in real exchange rates. One is through movements in the relative price of traded goods across countries $q^{T}$, second is movements in the international ratio $q^{N T}$. The first term $q^{T}$ is determined by the equilibrium condition of the balance of payments when net capital flows correspond to normal adjustment of the net foreign assets position $f$ towards its desired level $\widetilde{f}$. Defining the equilibrium for the external exchange rate $q^{T}$ as the exchange rate consistent with $f=\bar{f}$ i-e the exchange rate consistent with assets holdings at their targeted level, it follows that ${ }^{19}$

$$
\bar{q}^{T}=\frac{\left(i^{*}-g\right)}{\gamma} \bar{f} \quad \gamma>0
$$

where $g$ is the growth rate of nominal GDP and $i^{*}$ the international interest rate. The second term, $q^{N T}$ refers to the Balassa-Samuelson effect, which is driven by relative productivity in the tradable relative to nontradable sectors. The internal contribution to the equilibrium exchange rate $\bar{q}^{N T}$ can be expressed as:

$$
\bar{q}^{N T}=(1-\alpha)\left[\left(y^{T}-y^{N T}\right)-\left(y^{T *}-y^{N T *}\right)\right]
$$

where $y^{i}$ stands for labor productivity in sector $i,(i=N T, T)$.

From (3) et (4), we get the real equilibrium exchange rate, denoted $\bar{q}$ :

$$
\bar{q}=\frac{\left(i^{*}-g\right)}{\gamma} \bar{f}+(1-\alpha)\left[\left(y^{T}-y^{N T}\right)-\left(y^{T *}-y^{N T *}\right)\right]
$$

The real exchange rate $\bar{q}$ is expected to be a positive function of both the net foreign asset ${ }^{20}$ position $f$ and the relative productivity differential ${ }^{21}$

The net foreign assets is measured by the initial position plus the cumulative current account and cumulative net capital gains on cross border positions (Lane and Milesi-Ferretti, 2007). The literature on the determinants of the real exchange rate encompass two strands. The first one examines the role of net foreign assets taking it as an exogenous variable to other macroeconomic variables (Lane and Milesi-Ferretti $(2002,2004)$ ), and the second one as an endogenous variable (Masson et al., 1994; Cavallo and Ghironi,

\footnotetext{
${ }^{17}$ We refer to foreign variables with a star.

${ }^{18}$ Thus, an increase in $q$ represents an appreciation of the real exchange rate.

${ }^{19}$ See Alberola et al. (1999) for details.

${ }^{20} \mathrm{Net}$ foreign assets series are constructed as an interpolation of the updated dataset on world foreign asset and liabilities developed by Lane and Milesi-Ferretti $(2001,2006)$

${ }^{21}$ The relative productivity differential, which refers to the Balassa-Samuelson effect, is proxied by the ratio of consumer prices index to the producer prices index.
} 
2002; Ghironi, 2008). In the general framework of Alberola et al. (1999, 2002), net foreign assets position is viewed as an exogenous variable that influences real exchange rate. Theoretical approaches predict that real exchange rate appreciations should be associated with accumulation of net foreign assets in the long run. More specifically, in equilibrium, a country with negative net foreign assets must have trade surplus to finance the stream of interest and dividend payments, this trade surplus being associated with a depreciated real exchange rate. Conversely, a country which faces positive net foreign assets must have trade deficits in equilibrium.

The seminal works of Balassa (1964) and Samuelson (1964) provide an explanation of the long-run behavior of the real exchange rate in terms of productivity performance of traded relative to nontraded goods. The basic idea is that when productivity of traded goods rises relative to that of nontraded goods, there will be a tendency for the real exchange rate to appreciate. More specifically, Balassa (1964) and Samuelson (1964) showed that faster productivity growth in the tradable than in the nontradable sectors would lead to a decline in the relative price of tradables and hence to an appreciation of the real exchange rate.

The Balassa-Samuelson effects are generally thought to be the key source of observed cross-sectional differences in real exchange rates (i.e. the same currency prices of similar commodity baskets) between countries at different levels of income per capita.

Then, currency misalignments $\mathrm{cm}_{i t}$ are obtained as the deviation of the real exchange rate from its equilibrium level:

$$
c m_{i t}=q_{i t}-\bar{q}_{i t}
$$

where $\bar{q}_{i t}$ is defined as a set of fundamentals which are expected to have peristent effects on the long-run real exchange rate, namely the net foreign asset position and the relative productivity differential.

\subsection{Derivation of the indexes of undervaluation and overvaluation}

Undervaluation and overvaluation index are respectively defined as:

$$
q_{\text {under }}=\left(\text { mis } * D_{t}\right)
$$

and

$$
q_{\text {over }}=\left(\operatorname{mis} *\left(1-D_{t}\right)\right)
$$

where $D_{t}$ is a dummy variable equal to -1 if currency is undervalued and 0 otherwise. The decomposition of our series of misalignments in two indexes allows us to exclusively capture the period during which currencies are overvalued or undervalued. This distinction has never been made in a study before, including for instance works of Pesaran et al. (2004) or Bussière et al. (2009) who use effective exchange rates. The main drawback due to the use of effective exchange rates is the implicit assumption according to which depreciation and appreciation lead to symmetric effects. In other words, in a GVAR framework in which we use positive exchange rate shocks, we cannot disentangle the nature of the shock (overvaluationundervaluation). Indeed, it may represent the aggravation of an overvaluation or an undervaluation. So, isolating overvaluation of undervaluation enables us to consider only the aggravation of an overvaluation (the currency tends to be more overvalued) or the worsening of an undervaluation (the currency tends to be more undervalued.

Figure 1 exhibits some interesting features to analyze the main phases of undervaluation and overvaluation of the currencies of our studied countries. First, if we focus our attention on the three currencies -e.g. the euro, the U.S. dollar, and the renminbi- we see significant swings in the overvaluation / undervaluation over the whole studied period, particularly important for the American and European currencies. More precisely, except some short periods (1982Q2-1985Q3; 2001Q1-2004Q2; and 2008Q4-2009Q4), the renminbi is structurally underdalued. The devaluation in August 1994 has accentuated this feature. Two main episodes of overvaluation characterize the U.S. dollar. The first one corresponds to the dramatic nominal appreciation of the U.S. currency in the aftermath of the new monetary policy adopted from October 1979 (1980Q1-1987Q3). The second episode -from 1997Q4 to 2007Q3- occurs in the aftermath of several shocks affecting some trade partners of the United States (devaluation of Asian currencies in 1997-98; devaluation of the Brazilian real in January 1999) and the U.S. economy (such as the LTCM near-collapse in August 1998; the ENRON scandal in 2000 and the ICT bubble collapse in 2001). Between these two episodes of U.S. dollar overvaluation, Figure 1 displays a relatively long period of undervaluation from 
1987Q4 to 1996Q1. Overall, the U.S. dollar has been overvalued over the main part of our studied period (80 quarters out of 120).

The European currency has experienced two main episodes of undervaluation: from 1980Q1 to 1986Q3 on the one hand; from 1997Q2 to 2002Q4 in the aftermath of the effective introduction of the euro on the other hand. However, periods of euro overvaluation are predominant (64 quarters). Thus, Figure 1 exhibits a first overvaluation period from 1989Q4 to 1997Q1 while the second episode begins in 2003Q1. It is important to stress that from 1999 up to now, our misalignment measure fits relatively well the main swings in the nominal exchange rate of the euro.

Overall, our estimations of misalignments confirm the common wisdom according to which the Chinese currency tends to be undervalued relative to the euro and the U.S. dollar since the mid-1990s. The renminbi devaluation in 1994 and the associated tight control on the exchange rate via the de facto peg to the U.S. dollar introduce a break in the evolution of the Chinese currency. In addition, if we consider the relative sizes of the misalignments, we see that the renminbi experiences larger misalignments than the two other key currencies.

Second, among other advanced countries, overvaluation periods are more numerous than undervaluation ones in Australia, Canada, Japan, New-Zealand, Switzerland, and the United Kingdom. But the timing differs between these countries. More precisely, as suggested by Figure 1 , the Japanese yen has been overvalued since 1991; the Canadian dollar from 1980 to 1993 and once again since 2003; the GB pound in the first half of 80s' and from 1997 to 2008 -our misalignment measure fits very well the dramatic depreciation of the nominal effective exchange rate of the pound in the aftermath of the financial crisis; the NZ dollar in the 1980s and the 2000s; the Swiss franc from 1993 to 1996 and from 2002 to 2010; and the Australian dollar from 1980 to 1992 (except the period 1988Q2-1992Q1) and from 2003Q3 to 2009Q4. For all these countries except Switzerland, overvaluation periods have been preceded or followed by periods of undervaluation. In other words, these currencies exhibit relatively large swings in their misalignments. More precisely, the yen has been undervalued from 1980 to 1986; the Canadian dollar from 1994 to 2003; the GB pound from 1986 to 1996 (except over the period 1990Q2-1992Q4); the NZ dollar in the 1990s; and the Australian dollar from 1992 to 2003. Misalignments in Sweden show more episodes of undervaluation than overvaluation ones. The Swedish krona undervaluation occurs in the aftermath of the exchange rate crisis in September 1992 that leads to a devaluation of the Krona against the Ecu. Except over a short period -from 1995Q4 to 1996Q3- the Swedish krona has been constantly undervalued. As a result, Swedish is the only country of our sample to enter in the financial crises with an undervalued currency. Finally, Norway misalignment exhibits equivalent number of quarters with overvaluation and undervaluation (62 and 60 respectively). Such finding rests on a long period of undervaluation from 1991Q1 to 2001Q4) while the Norwegian krona has been overvalued since 2001.

Third, misalignments of the currencies in the emerging markets fit relatively well changes in exchange rate regimes. Recall that except Singapore that keeps its exchange rate regime over the all period, the other studied emerging economies have moved towards more flexible arrangements in the aftermath of the currency crises. More precisely, our measure of misalignments is in line with the literature stressing that hard pegs or rigid intermediate exchange rate regimes tend to favor real appreciation. In this perspective, Figure 1 shows clearly that the Korean won has been overvalued (or near its equilibrium value from 1980 to 1997) while the adoption of the floating regime in 1998 has been accompanied by a long period of undervaluation interrupted only from 2005Q1 to 2007Q4 under the pressure of the carry trade practice. Similarly, the Brazilian real has been overvalued from 1980 to 1998. In the aftermath of the real devaluation in January 1999, we observe a period of undervaluation from 1999Q1 to 2007Q1. Mexican peso follows a different path owing to the weak control on inflation exerted by Mexican authorities. As a result, the peso devaluation in December 1994 has stopped only temporally the overvaluation observed from 1991Q2 to 1994 Q4. Figure 1 shows a strong trend to overvaluation of the Mexican currency from 1997Q1 to 2008Q4. According to our misalignment measure, the Singaporean dollar has experienced more undervaluation episodes (70 quarters) than overvaluation ones (52 quarters). The main phases of undervaluation occur from 1986 to 1993 and from the end of 1998 to 2007. 
Figure 1: Misalignments based on the BEER methodology
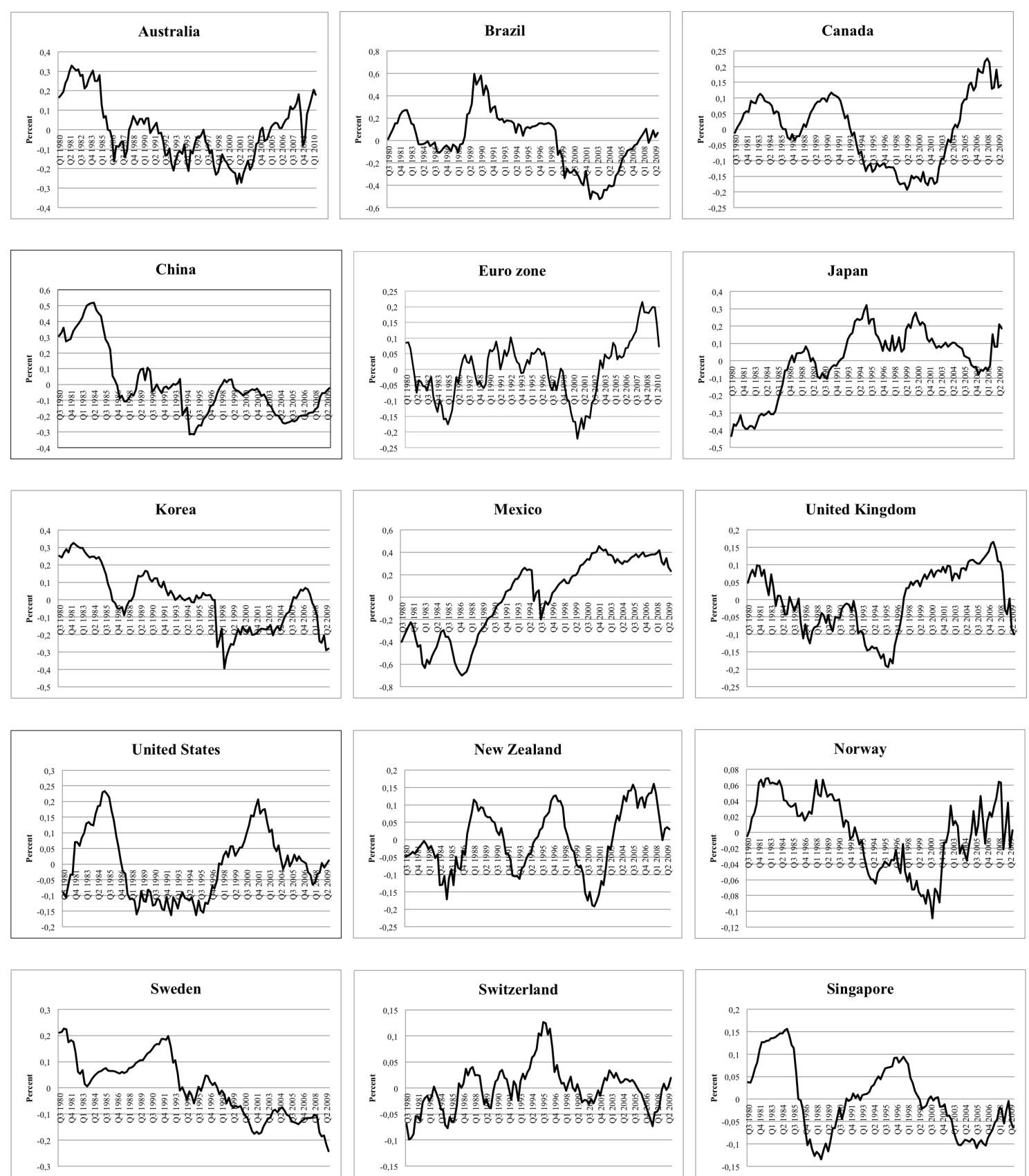

Note: positive misalignment: overvaluation, negative misalignment: undervaluation. 


\section{GVAR empirical results}

We adopt the GIRF methodology introduced by Koop et al. (1996) and Pesaran and Shin (1998) which aim at mesuring the effect of a shock on a variable at a given date on the value of all other variables ${ }^{22}$ Using the GIRF, unlike the orthogonalised impulse response functions, we do not impose a specific scheduling of the country/region. Then, the way the variable enters in the model has no impact on the results.

We compare positive shocks on undervaluation (Appendix B) and overvaluation (Appendix C) for our three key currencies: the U.S. dollar, the euro and the renminbi respectively. In order to see if undervaluation / overvaluation lead to symmetric effects, we compare them for each currency. More precisely, we consider the responses of the GDP, exports, and imports to these misalignments shocks ${ }^{23}$

It is important to stress that, in our framework, misalignments are exogenous. As a result, a shock to a currency misalignment does not affect the misalignment size of other currencies. To overcome this drawback, we consider in our comments the relative position of each currency using Figure $12^{24}$

\subsection{Shock to the U.S. dollar real exchange rate}

As expected, the U.S. real GDP increases in the aftermath of a positive undervaluation shock (See Appendix B, Table 1 1). On the impact, the size of the response is important $(0.359)$ and it reaches its maximum at the end of the period (0.491 at quarter 8$)$. In other words, the shock has a sizeable and a long-lasting effect on the real GDP. Such a result qualifies previous studies that find a moderate impact of real exchange rate shock on U.S. output (see, for instance, Bussière et al., 2009). The common argument explaining this weak impact is to stress that the United States is a relatively closed economy. Our result suggests that misalignments shock matter more than simple real exchange rate shock to analyze the influence of exchange rate changes on GDP fluctuations. If we consider the respective responses of the exports and imports, we observe in the two cases positive ones. More precisely, exports increase over the all period (1.052 at quarter 8) (See Appendix B, Table 1). The response of exports is an expected effect resulting from an increase in the size of the U.S. dollar undervaluation. The positive response of imports seems counterintuitive. Indeed, conventional theory tells that an increase in the undervaluation of the domestic currency raises imports prices and then tends to reduce the volume of imports. Our result exhibits the opposite. The size of the imports response is larger than exports one after quarter 4 (See Appendix B, Table 11). The maximum impact appears at quarter 8 (1.640). The discrepancy in the responses of exports and imports to a similar shock mirrors the so-called Houthakker-Magee asymmetry according to which the import side has higher income elasticity than the export side. Recall that, since 1965, the propensity to imports of the U.S. economy has increased significantly. In other words, a $x \%$ increase in the GDP is accompanied by a $\mathrm{x}+\mathrm{y} \%$ in imports. Trade specialization -for instance the increasing share of services in the U.S. GDP- in part explains such evolution. Overall, our result suggests that the increase in the U.S. dollar undervaluation has the usual expansionary effect on economic activity. But if we consider the expected impact of the U.S. dollar undervaluation on the current accounts adjustment, the strong response of imports that mirrors the high propensity to import of the U.S. economy tends to limit the ability of the exchange rate adjustment to reduce global imbalances. In other countries, GDP responses are positive except for China, Korea, and Norway (See Appendix B, Table 11. On the impact, the positive response of the GDP is especially sizeable for Singapore (0.349). The pattern of the GDP response exhibits a growing influence of the initial shock until quarter 4, but at the end of the period the response remains higher than the initial one. Recall that the share of the American economy in the international trade of Singapore has declined only since the last decade -a period where the U.S. dollar has been overvalued (See Figure 1). The positive responses of the

\footnotetext{
${ }^{22}$ For a detailed presentation of the GIRF methodology, see Dufrénot et al. (2004).

${ }^{23}$ Responses of the inflation rate are not reported because of insignificant results for all countries, as the same as Dees et al. (2007b). However, GIRF for inflation rate are available upon request.

${ }^{24}$ Despite this drawback, an interesting feature of the GVAR framework is that it allows to simulate the effects of various shocks to misalignments on trade flows. Such a simulation is not possible with the Fundamental Equilibrium Exchange Rate (FEER) approach. Indeed, in this approach, real equilibrium exchange rates are derived from trade equations or from trade models (in this case, the model simulates only shocks to real exchange rates). We thank the referee for drawing our attention on this question.
} 
GDP to an increase in the size of the U.S. dollar undervaluation in many of our studied countries confirm the leading role of the United States in the global economy. In other words, the U.S. dollar undervaluation induces a positive spillover effect. However, the positive impact remains relatively weak insofar as, except Brazil, Canada, and China, the sizes of the responses are inferior to 0.100 over the whole period.

China and Korea are puzzling exceptions since their GDP decreases in the aftermath of the shock. Korean economy exhibits a significant persistence effect. We see that the average negative response is -0.217 over the whole period. In China, if the response of the GDP stays negative over the whole period, the maximum influence of the shock appears on the impact (-0.184) while the average size of the response amounts to -0.115 . A possible explanation rests on the respective position of the won and renminbi in terms of misalignments. Figure 1 shows that the dollar undervaluation periods tend to correspond to won overvaluation ones. For the Chinese currency, the relationship is less clear since the size of the renminbi has been consistently higher than the U.S. dollar undervaluation. When significant, on the impact, the shock tends to exert a negative influence on exports in other countries (See Appendix B, Table 11). More precisely, exports decrease in all countries except Australia. Table 1 shows a long-lasting effect of the shock on exports. Indeed, we see that for all countries, the long-run GIRFs are superior to 0.350 . Western Hemisphere and Emerging Asia exhibit sizeable decreases in exports. In six out of 14 countries (e.g. Canada, Japan, Mexico, Sweden, Switzerland, and the United Kingdom), the shock has the expected effect on imports: they increase in the aftermath of the positive shock on U.S. dollar undervaluation (See Appendix B, Table 11. In other countries, and contrary to the economic intuition, imports decrease in the aftermath of the shock with a long-lasting effect. The negative responses are especially sizeable in Brazil, China, Korea, and Singapore. Indeed, in these countries, the GIRFs are over than 0.500. In other words, the positive shock on the U.S. dollar undervaluation leads to conflincting results concerning the responses of imports. Such result suggests that an increase in the U.S. dollar undervaluation may not induce sufficient effects on world imports to favor a correction in the global imbalances.

A positive shock on U.S. dollar overvaluation has a long-lasting restrictive impact on the U.S. GDP (from 0.224 on the impact to - 0.338 at quarter 8) (See Appendix C, Table 4). Such finding suggests that a shock on the U.S. dollar overvaluation has a significant impact on the GDP. Responses of U.S. exports contradict the conventional wisdom. Indeed, we observe that the shock is accompanied by an increase in exports over the all period (See Appendix C, Table 4). However, relative to exports responses to undervaluation shock, we see, as expected, that the positive effect on exports is lower for all horizons. Indeed, the average size of the responses to the overvaluation shock is 0.521 while it is 0.869 for the undervaluation one. As expected, imports increase in the aftermath of the shock but the response is significant only at short term (See Appendix C, Table 4). The weaker and insignificant response of U.S. imports to the shock suggests the presence of a very low pass-through of exchange rate changes to the U.S. import prices. Such low pass-through mutes the expenditure-switching effect of exchange rate changes on trade volumes ${ }^{25}$ The global influence of the shock on other countries GDP is weak at both short- and long-term (See Appendix C, Table 4). On the impact, the most influenced countries are South Korea (for negative responses, - 0.141) and China (for positive ones, 0.134). Exports exhibit the expected responses in the major part of our studied countries (see Appendix C, Table 4). Thus, the global impact of the positive shock on the U.S. dollar overvaluation is an increase in exports. Over time, we see that the stronger increases in exports concern Brazil, China, Mexico, and the Euro area where the average sizes of the responses are higher than 0.400. At the opposite, our results show that the main loosers in terms of exports are the United Kingdom and Sweden (average sizes: -0.260 and -0.148 respectively. On the impact, the shock has a narrow effect on imports except for Mexico (0.599), China (- 0.428), and Canada (- 0.215) (See Appendix C, Table 4). Over the long-run, the shock exerts a particularly strong significant, and positive, influence on imports in countries where advanced economies amount for more than $65 \%$ of the trade flows at the end of the period: Mexico (0.824), the Euro area (0.262), Sweden (0.264), and the United Kingdom (0.239). In addition, our results show a sizeable positive responses of imports in Japan (0.625) and Brazil (1.155). Interestingly, we see that in all East Asian countries except Japan, imports decrease in the aftermath of the shock.

\footnotetext{
${ }^{25}$ IMF (2007) finds that the United States have a lower pass-through to import prices than other OECD countries. In a similar vein, Chinn (2005) finds little evidence of cointegration between U.S. imports and the dollar real exchange rate. See also Hooper et al. (2000).
} 
Overall,we find that both U.S. exports and imports are more sensitive to undervaluation shock than to overvaluation one. In absolute value, the responses of the U.S. GDP to misalignments shocks are very near, even if, once again, we see a stronger response to undervaluation shock. In the rest of the world, we find no clear difference between the two shocks in terms of responses sizes. If we consider the GDP, the two shocks do not exert a negative impact. This suggests that the shocks do not seem too costly in terms of world growth. In addition if exports exhibit the expected results, imports react very differently among our studied countries. Imports do not seem to play a major role in the adjustment of global imbalances.

\subsection{Shock to the euro real exchange rate}

The increase in the size of the euro undervaluation is followed by a positive response of the real GDP of the Euro area (see Appendix B, Table 2). The size of the response is small -lower than 0.180- over the whole period suggesting a weak influence of the euro exchange rate on the European growth. This finding rests on the fact that, from a consolidated standpoint, the Euro area is a relatively closed economy. In addition, we must keep in mind that euro misalignments have been smaller than those concerning the dollar and the renminbi. The positive shock on the euro undervaluation exerts a positive influence on the exports from Euro area (See Appendix B, Table 2). The response is strong on the impact (0.329) followed by a continuous increase over time ( 0.507 at the end of the period). We observe the expected response for imports (See Appendix B, Table 2). Thus, after an increase in the size of the euro undervaluation, as prices of foreign goods denominated in euro tend to increase, the volume of imports decreases. The maximum decrease in imports is observed at quarter $3(-0.277)$ and the average size of the response is -0.226 . On the impact, the euro undervaluation shock on GDP in other countries is relatively weak, except for Singapore (- 0.371), Mexico (- 0.207), and the United Kingdom (0.141). The responses of other European countries are especially weak. On the one hand, as stressed by Bussière et al. (2009), these economies are very sensitive to Euro area output shocks. But, as show above, the Euro area's GDP does not strongly react to the euro undervaluation shock. On the other hand, Figure 1 suggests that in periods when the euro was undervalued, European currencies were either overvalued (Norway, Sweden, and the United Kingdom) or slightly undervalued (Switzerland).

In East Asian countries, Japan and China exhibit insignificant responses while GDP in Korea is weakly impacted by the shock (- 0.126 on average). Singapore exhibits the strongest response (- 0.382 on average). Euro undervaluation does not exert a restrictive influence on world exports (See Appendix B, Table 22. This finding may rest on the fact that the size of the euro undervaluation has been relatively small over the studied period. We see that the greatest responses of exports are observed in Japan (1.638 on the impact and 2.410 at the end of the period) and China ( 0.471 and 1.782 respectively). In part, these findings mirror the interdependencies included in our Global VAR model. More precisely, China, and Japan to a lesser extent, are the main beneficiaries from the positive GDP responses in the United Kingdom and the United States. Indeed, trade flows network discloses the fact that China and Japan are among the main trading partners of these countries. Once again, other European countries do not strongly react, except Sweden. Imports in the rest of the world portray a more mixed path (See Appendix B, Table 2). Positive responses are observed in the United States and East Asian countries except Singapore. For all these economies, the shock has a long-lasting effect on their imports. In other countries, imports decrease persistently especially in Brazil, Mexico, New Zealand, and Singapore. Other European countries are not strongly influenced by the shock. These findings are consistent with the previous results concerning the responses of GDPs in other countries to the undervaluation euro shock.

As expected, the positive shock on euro overvaluation has a restrictive impact on the GDP in Euro area (See Appendix C, Table 5. On the impact, the response is small (- 0.085) but it increases over time to -0.216 at the end of the period. Exports decrease in the aftermath of the shock (See Appendix C, Table 5). The contemporaneous response amounts to -0.280 while at the end of the period it climbs to -0.426 . Responses of imports to the shock are especially strong both on the impact (0.664) and at long-run (1.473 at quarter 8) (See Appendix C, Table 5). Overall, the shock produces the expected influences on the international trade of the Euro area, that is a fall in exports and an increase in imports. The impact of the shock on the GDP in other countries is clearly restrictive (See Appendix C, Table 55. Indeed, except Canada and China, 
all long-run responses are negative. On the impact, the shock has a weak effect. More precisely, the most impacted economies are Singapore (- 0.132) on the negative side and Sweden (0.143) on the positive one. The effect of the shock on the Swedish GDP is short-lived, as for Switzerland and the United Kingdom. The long-run impact of the shock is especially restrictive in Korea (- 0.359), Brazil (- 0.263), and Singapore (- 0.180). Broadly speaking, the effect of the shock on GDP in other countries is symmetric to the euro undervaluation shock, but the sizes of the responses tend to be higher in the latter case. For exports, the sizes of the responses are lower than in the euro undervaluation shock (See Appendix C, Table 5). The overall impact is negative for all countries except Brazil and China. In these countries, exports increase over the whole period ( 0.177 and 0.152 on the impact; 0.804 and 1.034 at quarter 8 respectively). As for the GDP, contemporaneous responses to the shock are small except for Sweden ( 0.790 on the impact) but the response decreases rapidly and is insignificant after quarter 4. On average, our results show that the strongest falls in exports are observed in Japan (- 0.420), Norway (- 0.384), and Singapore (- 0.402). In all other European countries -except Sweden- exports decrease over time in the aftermath of the shock. The global impact of the shock on imports is negative (See Appendix C, Table 5). The most affected economies are South Korea, Brazil, Mexico, and Japan.

The real exchange rate shocks of the euro have the expected impacts on exports and imports. In addition, we find that the euro overvaluation exerts a clear negative influence on the GDP of the Euro area. Our findings suggest the presence of asymmetric effects since undervaluation shocks exhibit stronger responses for GDP and exports relative to overvaluation shocks. We find the opposite for imports. Shocks to euro misalignments tend to exert a negative influence on world growth as we find that both undervaluation and overvaluations shocks lead to decreases in GDP. Finally, our results do not reveal significant asymmetric effects of the shocks in the rest of the world on the variables of interest.

\subsection{Shock to the renminbi real exchange rate}

Chinese GDP increases (0.182) on the impact of a positive shock on the renminbi undervaluation (See Appendix B, Table 3). The positive shock on the renminbi undervaluation exerts an expansionist effect on the economic activity over the whole period. The highest size of the GDP response appears at quarter 8 (1.086). The shock leads to a significant increase in Chinese exports. Table 3 (Appendix B) shows its long-lasting impact. Thus, at the end of the period, exports response to the initial shock amounts to 2.912 while the average size of the responses amounts to 1.856 . The strong influence of the shock on the Chinese international trade is confirmed by the response of imports. These latter decrease on the impact $(-1.249)$ and over the whole period (- 3.215 at quarter 8) (See Appendix B, Table 3). In other words, the undervaluation shock has the expected effects on imports and exports in China. Overall, we find that the renminbi undervaluation exerts a strong positive impact on the Chinese economy, but the main point is to determine to what extent the effect occurs to the detriment of the rest of the world.

If we consider the responses of the GDP to the shock in other countries (See Appendix B, Table 3), results lead to a striking conclusion: the global impact of increase in renminbi undervaluation is relatively restrictive. More precisely, GDP decreases in 10 countries out of 13 at all horizons. In all East Asian countries, GDP decreases, especially in Japan (- 0.308 on average) and Singapore (- 0.297 on average). It is important to stress that during episodes of renminbi undervaluation, other East Asian currencies have been overvalued (see Figure 1). GDP responses are positive only in two countries: the Euro area and the United States, but the sizes of the responses are relatively small (on average, 0.281 and 0.164 respectively). The positive shock on renminbi undervaluation exerts a mixed influence on exports in our studied countries (See Appendix B, Table 3). Exports increase over the whole period in Australia (0.404 on average), Canada (0.608 on average), Japan (2.2015 on average), Sweden (0.670 on average), and the United Kingdom (0.691 on average). At the opposite, other countries suffer from a decline in their exports, mainly Brazil (- 1.906 on average), Mexico (- 1.230 on average), Singapore (- 2.738 on average), the United States (- 0.807 on average), and the Euro area (- 0.530 on average). Above all, the sizes of the negative responses are higher than the size of the positive ones. The shock leads to negative responses of imports in all countries (See Appendix B, Table 3). On the impact, the most affected countries are South Korea (- 0.522) and Brazil (0.252). At long-run, the decrease in imports is especially strong for Singapore (- 0.926), Brazil (- 1.232), 
and the United States (- 1.259). Overall, the shock on the renminbi undervaluation exerts a negative influence -that increases after one year- on GDP growth in the rest of the world. We find also that its influence on international trade -and, in turn, on global imbalances- is significant from an economic standpoint.

In China, GDP contracts in the aftermath of a positive shock on the renminbi overvaluation (See Appendix $\mathrm{C}$, Table 6). The contemporaneous response is relatively strong (- 0.414). The negative impact of the shock remains stable over time. Interestingly, we find that the restrictive impact of the shock on the renminbi overvaluation is lower than the expansionist one of the shock on undervaluation. More precisely, the average size of the responses is -0.473 in the former shock while it amounts to 0.698 for the latter. As expected, the shock leads to a decrease in Chinese exports (See Appendix C, Table 6). However, at all horizons the shock has a weak effect on exports (less than 0.05). Thus, exports are considerably less sensitive to renminbi overvaluation than to undervaluation. Except on the impact, imports do not react to a positive shock on renminbi overvaluation (See Appendix C, Table 6). Indeed, we find that, if on the impact, the response is negative and important (- 0.737), it falls to - 0.09 at quarter 1 . Beyond, the responses are statistically insignificant. As exports, Chinese imports are less sensitive to a renminbi overvaluation than to an undervaluation. Except the Euro area, Norway (over one quarter), and Japan (over three quarterrs), the responses of GDP to the shock are positive (See Appendix C, Table 6). On the impact, the size of the responses is weak for all studied countries suggesting that the impact of a renminbi overvaluation on the world growth appears after a lag. At quarter 8, Brazil, Sweden, and New Zealand experience the strongest positive responses of exports. The overall impact of the shock on exports in other countries is positive (see Appendix C, Table 6). Brazil, Japan, and Singapore exhibit the most important increase in exports. In all studied countries, we find an increase in imports in the aftermath of the shock (See Appendix C, Table 6. On the impact, positive responses are the strongest in Brazil (0.192) and the Euro area (0.158). At long-run, Brazil experiences the highest response (3.045), followed by Mexico (1.571) and Canada (1.146).

Overall, the shock on renminbi undervaluation exerts a stronger influence on GDP fluctuations than a shock on overvaluation in both China and the rest of the world. If these shocks have the expected effects on the Chinese GDP, we find that Chinese exports and imports do not strongly react to overvaluation shocks. In addition, we see that the renminbi undervaluation exerts a negative influence on world growth (proxied by the negative responses of the GDP) while we find the opposite for the overvaluation shocks. Interestingly, our results show that other Asian countries are sensitive to shocks on renminbi. This finding contradicts Arndt (2005) who stresses that the cross-border production sharing in East and South-East Asian area diminishes the sensitivity of trade flows to exchange rate swings. Our results suggest that exchange rate matters in East Asia. Finally, focusing our attention on the U.S.-Chinese trade debates, we find that the United States do not seem dramatically suffer -in terms of growth- from a shock on renminbi undervaluation. In terms of global imbalances, we see that the undervaluation shocks depresses U.S. exports while we observe the opposite for overvaluation shock. Such a result may seem counterintuitive but may be explained by the interdependencies included in a GVAR model.

\section{Generalized forecast error variance}

The generalized forecast error variance allows us to estimate the influence of the shocks to real exchange rates on domestic variables. In other words, it gives information about the proportion of the variance of the h-step ahead forecast errors of each domestic variable explained by the real exchange rate shocks of our three key currencies. Considering that our main variable of interest is the GDP of our studied countries, Appendix D exhibits the contribution of shocks to undervaluation (overvaluation) of the U.S. dollar, euro, and renminbi in generalized forecast error variances (GFEV thereafter) of the GDP.

The U.S. dollar undervaluation shock exerts a strong influence on the U.S. GDP GFEV at all horizons. Indeed, the shock explains $44.3 \%$ of the contemporaneous GFEV while it climbs to $50 \%$ at horizon 8 . Interestingly, we see that both the GDPs in China and Euro area are significantly influenced by the shock. In other words, our results suggest that the dollar continues to play a pivotal role in the world economy. More precisely, Table 7 in Appendix D shows that China (24.6\% at the contemporaneous horizon and 27.2\% 
at the end of the period) and Euro area (49.9\% and $40.4 \%$ respectively) are among the most influenced countries at all horizons. The shock accounts for more than $10 \%$ of the GDP GFEV in Australia, Canada, Japan, Korea, and the United Kingdom, while the GFEVs of our other countries are weakly explained by the shock.

The shock on U.S. dollar overvaluation exerts a stronger influence on the U.S. GDP (See Appendix D, Table 8). It accounts for $57.1 \%$ of the contemporaneous GFEV and $68.7 \%$ at horizon 8 . In other words, our results suggest that in terms of macroeconomic fluctuations the former shock is more significant than the latter one. We observe that the overvaluation shock contributes for a higher amount to the GFEVs in the rest of the world at all horizons. At the shortest horizon, all countries are affected by the shock except Sweden (6.0\%) and Norway (2.0\%). At long-term, Western Hemisphere, East Asian countries, New Zealand, and the Euro area are mostly influenced by the shock. Thus, the share of the GDP variance explained by the shock is higher than $20 \%$.

Overall, our main findings are striking. On the one hand, the shock on U.S. dollar misalignments exerts a strong and significant influence on our two other main economies (China and the Euro area). Such a result suggests the presence of intense interdependences between these countries via the exchange rate channel measured in our paper in terms of shocks to misalignments. On the other hand, we see that the shock on U.S. dollar overvaluation contributes for a higher share of the GDPs generalized forecast error variances.

The Euro area GDP is significantly influenced by the shock on euro undervaluation. Its contemporaneous influence explains $39.1 \%$ of the GFEV but it losts relevance over time since it accounts for $31.6 \%$ of the GFEV at horizon 8 (See Appendix D, Table 7). In other countries, the relative importance of the shock increases over time (see Table 7). Interestingly, whatever the time horizon, our results exhibit a striking feature: the GDPs of China (25.2\% at the contemporaneous horizon and $17.2 \%$ at horizon 8 ) and the United States (39.3\% and 30.4\% respectively) are among the most influenced economies. In addition, the shock on euro undervaluation tends to exert a stronger influence on the GDPs of advanced countries (except Japan) relative to emerging economies. At short-run, the shock accounts for more than $20 \%$ of the GDP variance for the United Kingdom, Sweden, Singapore, Norway, and Canada. At long-run, the most influenced economies are Canada (38.6\%), the United Kingdom (34.8\%), and Sweden (31.1\%).

Table 8(Appendix D) displays an interesting finding: the shock on euro overvaluation contributes to higher shares of GDPs GFEVs than the undervaluation shock. This finding is observed not only for the Euro area, but also for the rest of the world. As stressed in the analysis of the generalized impulse responses functions, it is important to recall that the size of the euro overvaluation has been higher than the size of the undervaluation over our studied period. For the Euro area, we see that the overvaluation shock accounts for $48.1 \%$ of the contemporaneous GDP GFEV. The influence of the shock increases over time: at horizon 12, it explains $51.1 \%$ of the GDP GFEV. At the shortest horizon, all countries are significantly influenced by the shock, especially European economies. Japan is the country for which the share of the GDP explained by the shock is the lowest $(14.1 \%)$. The long-run influence of the euro overvaluation shock is especially strong for the most advanced countries (Japan, Singapore, and the United Kingdom) and for countries in which industrialized economies continue to represent a significant share of their trade flows (New Zealand, Mexico, and other European countries). The only exception is Canada for which the share of the GDP variance explained by the shock decreases rapidly $(41.8 \%$ at the contemporaneous horizon; $15.9 \%$ at horizon $6 ; 9.2 \%$ at horizon 8$)$. The United States are the most influenced country $(55.5 \%$ contemporaneously and $54.3 \%$ at horizon 12) while the shock accounts for more than $20 \%$ of the Chinese GDP variance at all horizons (with a maximum value ate horizon $3(41.8 \%)$.

Our results confirm the key role of the euro in the world economy. Indeed, we find that misalignments shocks of the European currency exert a significant influence on macroeconomic fluctuations in China and the United States. We also show that the overvaluation shock is more significant than the undervaluation one.

The shock on renminbi undervaluation contributes mostly for the Chinese GDP GFEV insofar as it accounts for $46.8 \%$ of the GDP contemporaneous variance and $53.3 \%$ at horizon 8 . It contributes the most at 
horizon 4 (56.5\% of the GFEV) (See Appendix D, Table 7). GDPs in other Asian economies are significantly infuenced by the shock at all horizons. More precisely, on average, the shock explains $22.3 \%$ of the GDP variance in Japan, $17.1 \%$ in South Korea, and 21.9\% in Singapore. Such finding confirms the regional influence of China. Table 7 (Appendix D) shows also that the Euro area and the United States are not immune from the renminbi undervaluation shock. More precisely, on average, the shock accounts for $15.3 \%$ and $14.9 \%$ of their GDP variance respectively. We see also that the GFEVs in the two countries increase over time. Other countries are weakly influenced by the shock except Brazil and the United Kingdom.

The shock on renminbi overvaluation exhibits a stronger influence on the Chinese GDP GFEV at all horizons than the undervaluation one (53.1\% at the shortest horizon and $69.2 \%$ at the longest one) (See Appendix D, Table 7). When statistically significant, both at short- and long-terms, the shock accounts for a higher share of the GDPs generalized forecast error variances in all countries ${ }^{26}$ As for the undervaluation shock, we find that the Euro area (36.3\% on average) and the United States (37.6\% on average) are especially influenced by the shock on renminbi overvaluation. In the two countries, the shock gains in significance over time ( $42.9 \%$ and $56.08 \%$ at horizon 8 respectively). In other countries, the shock explains, on average, more than $10 \%$ of the GDP variance except Sweden.

Overall, as for the U.S. dollar and euro shocks, we find that the renminbi exerts a significant influence on the world economy. Indeed, shocks to renminbi misalignments explain significant shares of the GDPs variances in many of our studied countries.

\section{Conclusion}

This paper sought to analyse to what extent currency misalignments affect current accounts and economic growth in a multilateral framework. By considering both side of misalignments, namely overvaluation and undervaluation phases, we attempt to provide some new answers regarding the exchange rate fluctuations and economic growth linkage. The empirical strategy adopts the GVAR approach, which allows for interdependences, thus constituting a very appropriate framework to consider spillover effects.

We focus on the exchange rate dynamics and the impact of the overvaluation (resp. undervaluation) of the dollar, the euro and the renminbi on their economic growth as well as on economic performance of many other developed and emerging countries. Our main findings can be summarized as follows. Firstly, we highlight the asymmetric effect of misalignement insofar as overvaluation and undervaluation shocks do not lead to similar size effects. Secondly, our results suggest that the United States continue to exert a significant influence on the world economy, as stressed by Dees and Saint-Guilheme (2011). Indeed, GDP of our studied countries react to U.S. dollar misalignments, including China and the Euro area. However, we state that dollar adjustment does not seem to be able to play a major role in global rebalancing. Thirdly, turning to the euro, it does not seem that overvaluation and/or overvaluation have a strong significant impact on the Euro area and more widely on world economic growth, mainly if we consider the impact of the euro misalignments on the exports levels. Finally, if we confirm the fact that China benefits from the renminbi undervaluation, our results suggest that the corresponding negative impact on the other countries is economically significant.

The policy implications of our results are twofold. First, if exchange rate adjustment matter to reduce global imbalances, our findings suggest that we must not wait too much about the magnitude of this influence. Indeed, responses concerning exports and imports to overvaluation and undervaluation shocks are mixed. For instance, if undervaluation shocks tend to favor exports in our three countries, we find that overvaluation shocks exert a negative influence on exports only in China and the Euro area. Second, in the rest of the world, one of our striking results is the fact that the renminbi undervaluation (overvaluation) exerts a contractionary (expansionary) impact on world growth. In a similar vein, we find that the renminbi undervaluation is costly for exports from the rest of the world while it overvaluation tends to favor them. In addition, misalignments of the three key currencies exert a significant influence on the GDP variance in many other countries. As for the Chinese currency, the U.S. dollar undervaluation (overvaluation) reduces

\footnotetext{
${ }^{26}$ The generalized forecast error variances are insignificant for Korea, Japan from horizon 4, and Norway from horizon 2.
} 
(increases) exports from the rest of the world. In other words, other countries are not immune from curreny undervaluation or overvaluation in a specific country. As a result, it seems very relevant to monitor exchange rates in a multilateral perspective.

\section{References}

Aguirre, A., Calderon, C., 2005. Real exchange rate misalignments and economic performance, Central Bank of Chile Working Paper 315, April.

Alberola, E., 2002. Misalignment, liabilities dollarization and exchange rate adjustment in Latin America, Banco de Espana, Documento de trabajo, N. 309.

Alberola, E., Cervero, S.G., Lopez H., Ubide, A., 1999. Global equilibrium exchange rates: euro, dollar, ins, out and other major currencies in a panel cointegration framework, IMF Working Paper 175, December.

Allegret, J.P., Essaadi, E., 2011. Business cycles synchronization in East Asia economy: evidences from time-varying coherence study, Economic Modelling, 28(1-2): 351-365.

Angeloni, I., Bénassy-Quéré, A., Carton, B., Destais, C., Darvas, Z., Pisani-Ferry, J., Sapir A., Vallèe, S., 2011. Global currencies for tomorrow: a European perspective, Bruegel Blueprint Series-CEPII Research Reports, Brussels and Paris.

Arndt, S.W., 2005. Cross-border production sharing and exchange rates in East Asia, Asia Pacific Economic Association Conference, Tokyo, July.

Arslan R, Rapetti M. and Skott P. (2012), The real exchange rate and economic development, Structural Change and Economic Dynamics, 23(2): 151-169.

Balassa, B., 1964. The purchasing power parity doctrine: a reappraisal, Journal of Political Economy, 72(6): 584-596.

Baxter, M., Kouparitsas, M.A., 2005. Determinants of business cycle comovements: a robust analysis, Journal of Monetary Economics, 52(1): 113-157.

Berg, A., Miao, Y., 2010. The real exchange rate and growth revisited: the Washington Consensus strikes back?, IMF Working Papers, 10/58, March.

Blanchard, O., Milesi-Ferretti, G.M., 2011. (Why) should current account balances be reduced?, IMF Staff Discussion Note, March, SDN/11/03, Washington D.C.

Brender, A., Pisani, F., 2010. Global imbalances and the collapse of globalized finance, Centre for European Policy Studies, Dexia, Belgium.

Bussière, M., Chudik, A., Sestieri, G., 2012. Modelling global trade flows, results from a GVAR model, Federal Reserve Bank of Dallas Globalization and Monetary Policy Institute, Working Paper No. 119, June.

Cavallo, M., Ghironi, F., 2002. Net foreign assets and the exchange rate: redux revived, Journal of Monetary Economics 49(5): 1057-97.

Chinn, M.D., 2005. Doomed to deficits ? Aggregate U.S. trade flows re-examined, Review of World Economics, 141(3): 460-485.

Chinn, M.D., Wei, S.J., 2013. A faith-based initiative: does a flexible exchange rate regime really facilitate current account adjustment?, Review of Economics and Statistics, 95(1): 168-184.

Chiu, Y.B., Lee, C.C., Sun, C.H., 2010. The U.S. trade imbalance and real exchange rate: an application of the heterogeneous panel cointegration method, Economic Modelling 27(3): 705-716.

Cline, W.R., Williamson, J., 2010. Currency wars?, Peterson Institute for International Economics, Policy Brief, PB 10-26, November, Washington D.C.

Dees, S., Saint-Guilhem, A., 2011. The role of the United States in the global economy and its evolution over time, Empirical Economics, 41(3): 573-591

Dees, S., Holly, S., Pesaran, M.H., Smith, L.V., 2007a. Long-run macroeconomic relations in the global economy, Economics, the Open Access, Open Assessment E-Journal, Kiel Institute for the World Economy, 1(3).

Dees, S., Di Mauro, F., Pesaran, M.H., Smith, L.V., 2007b. Exploring the international linkages of the Euro area: a Global VAR analysis, Journal of Applied Econometrics, 22(1): 1-38.

Dufrénot, G., Mignon, V., Peguin-Feissolle, A., 2004. Business cycles asymmetry and monetary policy: a further investigation using MRSTAR models, Economic Modelling, 21(1): 37-71. 
Engle, R.F., Hendry, D.F., Richard, J-F., 1983. Exogeneity, Econometrica, 51(2): 277-304.

Forbes, K.J., Chinn, M.D., 2004. A decomposition of global linkages in financial markets over time, The Review of Economics and Statistics, 86(3): 705.722.

Funabashi, Y., 1988 Managing the dollar: from the Plaza to the Louvre, Institute for International Economics, Washington D.C.

Ghironi, F., 2008. The role of net foreign assets in a new Keynesian small open economy model, Journal of Economic Dynamics and Control, 32(6): 1780-811.

Greenwood-Nimmo, M., Viet Nguyen, H., Shin, Y., 2012. International linkages of the Korean macroeconomy: the Global VAR modelling approach, Journal of Market Economy, 41(3): 15-64.

Granger, C.W.J., Lin, J.L., 1995. Causality in the long run, Econometric Theory, 11(3): 530-536.

Haltmaier, J.T., Ahmed, S., Coulibaly, B., Knippenberg, R., Leduc, S., Marazzi, M., Wilson, B.A., 2007. The role of China in Asia: engine, conduit, or steamroller?, Board of Governors of the Federal Reserve System: International Finance Discussion Paper, 904, September.

Harbo, I., Johansen, S., Nielsenand, B., and Rahbek, A., 1998. Asymptotic inference on cointegrating rank in partial systems, Journal of Business Economics and Statistics 16(4): 388-399.

Hooper, P., Johnson, K., Marquez, J., 2000. Trade elasticities for the G-7 countries, Princeton Studies in International Economics, 87, August.

Imbs, J,. 2004. Trade, finance, specialization and synchronization, The Review of Economics and Statistics, 86(3): 723-734.

IMF, 2007. Exchange rates and the adjustment of external imbalances, World Economic Outlook, chapter 3, April, Washington DC.

Isard, P., Faruqee, H., Kincaid, G.R., Fetherston, M., 2001. Methodology for current account and exchange rate assessments, IMF Occasional Paper, 209, Washington D.C.

Kappler, M., Reisen, H., Schularick, M., Turkisch, E., 2013. The macroeconomic effects of large exchange rate appreciations, Open Economies Review, 24(3): 471-494.

Lane, P.R., Milesi-Ferretti, G.M., 2007. The external wealth of nations Mark II: revised and extended estimates of foreign assets and liabilities, 1970-2004, Journal of International Economics 73(2): 223-50.

2002. External wealth, the trade balance, and the real exchange rate, European Economic Review, 46(6): 1049-71.

2004. The transfer problem revisited: net foreign assets and real exchange rates, Review of Economics and Statistics 86(4): 841-57.

Masson, P.R., Kremers, J., Horne, J., 1994. Net foreign assets and international adjustment: the United States, Japan and Germany, Journal of International Money and Finance 13(1): 27-40.

Mattoo, A., Mishra, P., Subramanian, A., 2012. Spillover effects of exchange rates: A study of the renminbi, Peterson Institute for the International Economics, Working Paper Series, WP 12-4, March, Washington D.C.

Pesaran, M.H., Schuermann, T., Weiner, S.M., 2004. Modelling regional interdependencies using a global error-correcting macroeconometric model, Journal of Business and Economics Statistics, 22(2): 129-162.

Pesaran, M.H., Smith, R. P., 2006. Macroeconomic modelling with a global perspective, Manchester School, University of Manchester, 74(1): 24-49.

Portes, R., 2010. Currency wars and the emerging-market countries, Voxeu, 4 November.

Rapetti, M., 2013. Macroeconomic policy coordination in a competitive real exchange rate strategy for development, Journal of Globalization and Development, 3(2): 1-31.

Rault, C., 2004. Further results on weak-exogeneity in vector error correction models, Econometric Society 2004 Far Eastern Meetings 402, Econometric Society.

Richard, J.F., 1980. Models with several regimes and changes in exogeneity, Review of Economic Studies, 47(1): 1.20.

Rodrik, D., 2008. The real exchange rate and economic growth, Brookings Papers on Economic Activity, 2: 365-412.

Sallenave, A., 2009. Real exchange rate misalignments and economic performance for the G20 Countries, International Economics, 121: 59-80.

Samuelson, P., 1964. Theoretical notes on trade problems, Review of Economics and Statistics, 46(2): $145-154$ 
Sgherri, S., Galesi, A., 2009. Regional financial spillovers across Europe:a Global VAR analysis, IMF Working Papers 09/23, February.

Skott, P., Rapetti, M., Arslan, R., 2012. Real exchange rates and the long-run effects of aggregate demand in economies with underemployment, Working Papers 2012-06, University of Massachusetts Amherst, Department of Economics.

Williamson J. (1983), The exchange rate system, Institute for International Economics, Policy Analyses in International Economics, September, Washington D.C.

Williamson, J., Marcus, M., 1987. Targets and indicators: a blueprint for the international coordination of economic policy, Washington, DC: Institute for International Economics. 


\section{Appendix A - Data sources}

\begin{tabular}{ccccccc}
\hline Countries & ner & CPI & real GDP & inflation rate & PPI & nfa \\
\hline Australia & IFS & IFS & PSW & PSW & IFS & Lane \& Milesi-Ferretti \\
Brazil & IFS & IFS & PSW & PSW & IFS & Lane \& Milesi-Ferretti \\
Canada & IFS & IFS & PSW & PSW & IFS & Lane \& Milesi-Ferretti \\
China & IFS & IFS & PSW & PSW & IFS & Lane \& Milesi-Ferretti \\
Japan & IFS & IFS & PSW & PSW & IFS & Lane \& Milesi-Ferretti \\
Korea & IFS & IFS & PSW & PSW & IFS & Lane \& Milesi-Ferretti \\
Mexico & IFS & IFS & PSW & PSW & IFS & Lane \& Milesi-Ferretti \\
Norway & IFS & IFS & PSW & PSW & IFS & Lane \& Milesi-Ferretti \\
New Zealand & IFS & IFS & PSW & PSW & IFS & Lane \& Milesi-Ferretti \\
Singapore & IFS & IFS & PSW & PSW & IFS & Lane \& Milesi-Ferretti \\
Sweden & IFS & IFS & PSW & PSW & IFS & Lane \& Milesi-Ferretti \\
Switzerland & IFS & IFS & PSW & PSW & IFS & Lane \& Milesi-Ferretti \\
United Kingdom & IFS & IFS & PSW & PSW & IFS & Lane \& Milesi-Ferretti \\
United States & IFS & IFS & PSW & PSW & IFS & Lane \& Milesi-Ferretti \\
Euro area & Datastream & IFS & PSW & PSW & IFS & Lane \& Milesi-Ferretti \\
\hline
\end{tabular}

Note:

(i) PSW referred to the online database avaible on the Pesaran's web page:

http://www.econ.cam.ac.uk/faculty/pesaran/wp.htm

(ii) Lane \& Milesi-Ferretti referred to the online database avaible on the following web page:

http://www.imf .org/external/pubs/cat/longres. cfm?sk=18942.9

\begin{tabular}{ccccc}
\hline Countries & exportations & importations & undervaluation & overvaluation \\
\hline Australia & OECD & OECD & author's calculation & author's calculation \\
Brazil & OECD & OECD & author's calculation & author's calculation \\
Canada & OECD & OECD & author's calculation & author's calculation \\
China & OECD & OECD & author's calculation & author's calculation \\
Japan & OECD & OECD & author's calculation & author's calculation \\
Korea & OECD & OECD & author's calculation & author's calculation \\
Mexico & OECD & OECD & author's calculation & author's calculation \\
Norway & OECD & OECD & author's calculation & author's calculation \\
New Zealand & OECD & OECD & author's calculation & author's calculation \\
Singapore & OECD & OECD & author's calculation & author's calculation \\
Sweden & OECD & OECD & author's calculation & author's calculation \\
Switzerland & OECD & OECD & author's calculation & author's calculation \\
United Kingdom & OECD & OECD & author's calculation & author's calculation \\
United States & OECD & OECD & author's calculation & author's calculation \\
Euro area & OECD & OECD & author's calculation & author's calculation \\
\hline
\end{tabular}


Appendix B - GIRF analysis (undervaluation)

Table 1: Generalized Impulse responses of a positive one standard error shock to U.S. dollar undervaluation

\begin{tabular}{|c|c|c|c|c|c|c|c|c|c|}
\hline & \multicolumn{3}{|c|}{ Impact on real gdp(\%) } & \multicolumn{3}{|c|}{ Impact on exports(\%) } & \multicolumn{3}{|c|}{ Impact on real imports(\%) } \\
\hline & impact & 4 & 8 & impact & 4 & 8 & impact & 4 & 8 \\
\hline Australia & 0,064 & 0,035 & 0,026 & 0,146 & $\mathbf{0 , 1 2 9}$ & $\mathbf{0 , 1 3 6}$ & $-0,173$ & $-0,294$ & $-0,232$ \\
\hline Brazil & 0,100 & 0,142 & 0,136 & $-1,107$ & $-2,295$ & $-2,997$ & $-1,180$ & $-0,779$ & $-0,664$ \\
\hline Canada $^{\mathrm{a}}$ & 0,104 & 0,127 & 0,144 & - & - & - & 0,222 & 0,114 & 0,208 \\
\hline China & $-0,184$ & $-0,077$ & $-0,151$ & $-0,921$ & $-0,766$ & $-0,356$ & $-0,138$ & $-0,702$ & $-1,051$ \\
\hline Japan $^{\mathrm{a}}$ & 0,151 & 0,201 & 0,187 & - & - & - & 0,102 & 0,175 & 0,246 \\
\hline Korea $^{a}$ & $-0,207$ & $-0,217$ & $-0,215$ & - & - & - & $-0,575$ & $-0,505$ & $-0,503$ \\
\hline Mexico & 0,064 & 0,035 & $-0,019$ & $-0,177$ & $-0,786$ & $-0,946$ & 0,111 & 0,279 & 0,391 \\
\hline Norway $^{\mathrm{a}}$ & $-0,229$ & $-0,169$ & $-0,177$ & - & - & - & $-0,296$ & $-0,193$ & $-0,108$ \\
\hline New Zealand ${ }^{\mathrm{a}}$ & 0,041 & 0,057 & 0,049 & - & - & - & $-0,361$ & $-0,396$ & $-0,345$ \\
\hline Singapore & 0,349 & 0,525 & 0,470 & $-0,649$ & $-2,699$ & $-3,542$ & $-1,497$ & $-1,135$ & $-1,044$ \\
\hline Sweden & 0,089 & 0,077 & 0,050 & $-0,149$ & $-0,678$ & $-0,723$ & 0,107 & 0,202 & 0,290 \\
\hline Switzerland & 0,056 & 0,073 & 0,054 & $-0,031$ & $-0,652$ & $-0,816$ & 0,101 & 0,181 & 0,217 \\
\hline United Kingdom & 0,049 & 0,079 & 0,064 & $-0,347$ & $-0,395$ & $-0,423$ & 0,078 & 0,118 & 0,146 \\
\hline United States & 0,359 & 0,439 & 0,491 & 0,487 & 0,862 & 1,052 & 0,118 & 0,987 & 1,640 \\
\hline Euro area & 0,079 & 0,086 & 0,073 & $-0,273$ & $-0,628$ & $-0,716$ & $-0,066$ & $-0,106$ & $-0,058$ \\
\hline
\end{tabular}

${ }^{a}$ GIRF is not signifiant for the bootsraped $95 \%$ interval confidence.

Note: Insignificant results are reported in bold.

Table 2: Generalized Impulse responses of a positive one standard error shock to euro undervaluation

\begin{tabular}{|c|c|c|c|c|c|c|c|c|c|}
\hline & \multicolumn{3}{|c|}{ Impact on real gdp(\%) } & \multicolumn{3}{|c|}{ Impact on exports(\%) } & \multicolumn{3}{|c|}{ Impact on real imports(\%) } \\
\hline & impact & 4 & 8 & impact & 4 & 8 & impact & 4 & 8 \\
\hline Australia $^{\mathrm{a}}$ & & - & - & $-0,376$ & $-0,342$ & $-0,356$ & $-0,258$ & $-0,067$ & $\mathbf{0 , 0 2 4}$ \\
\hline Brazil $^{\mathrm{a}}$ & - & - & - & - & - & - & $-0,818$ & $-0,372$ & 0,062 \\
\hline Canada $^{\mathrm{a}}$ & $-0,067$ & $-0,140$ & $-0,150$ & - & - & - & $-0,273$ & $-0,206$ & $-0,082$ \\
\hline China $^{\mathrm{a}}$ & - & & - & 0,471 & 1,486 & 1,782 & 0,111 & 0,106 & 0,089 \\
\hline Japan $^{\mathrm{a}}$ & - & - & - & 1,638 & 2,054 & 2,410 & 0,093 & 0,197 & 0,253 \\
\hline Korea $^{a}$ & $-0,092$ & $-0,114$ & $-0,122$ & - & - & - & 0,212 & 0,331 & 0,348 \\
\hline Mexico $^{\mathrm{a}}$ & $-0,207$ & $-0,294$ & $-0,283$ & - & - & - & $-0,610$ & $-0,417$ & $-0,171$ \\
\hline Norwa & $-0,087$ & $-0,085$ & $-0,074$ & - & - & - & - & - & - \\
\hline New Zealand ${ }^{a}$ & $-0,051$ & $-0,098$ & $-0,107$ & - & - & - & $-0,563$ & $-0,443$ & $-0,367$ \\
\hline Singapore & $-0,371$ & $-0,375$ & $-0,384$ & 0,197 & 0,231 & 0,294 & $-0,475$ & $-0,080$ & 0,149 \\
\hline Sweden & $-0,068$ & $-0,086$ & $-0,107$ & 0,404 & 0,897 & 1,007 & $-0,120$ & 0,048 & 0,175 \\
\hline Switzerland & $-0,066$ & $-0,073$ & $-0,079$ & $-0,266$ & $-0,437$ & $-0,478$ & $-0,125$ & $-0,091$ & $-0,146$ \\
\hline United Kingdom & 0,141 & 0,350 & 0,447 & $-0,222$ & $-0,144$ & $-0,119$ & $-0,113$ & 0,077 & 0,177 \\
\hline United Sta & 0,072 & 0,076 & 0,078 & 0,118 & 0,266 & 0,322 & 0,908 & 1,186 & 1,338 \\
\hline Euro area & 0,088 & 0,173 & 0,231 & 0,329 & 0,474 & 0,507 & $-0,166$ & $-0,256$ & $-0,175$ \\
\hline
\end{tabular}

${ }^{a}$ GIRF is not signifiant for the bootsraped $95 \%$ interval confidence.

Note: Insignificant results are reported in bold. 
Table 3: Generalized Impulse responses of a positive one standard error shock to China undervaluation

\begin{tabular}{|c|c|c|c|c|c|c|c|c|c|}
\hline & \multicolumn{3}{|c|}{ Impact on real gdp(\%) } & \multicolumn{3}{|c|}{ Impact on exports(\%) } & \multicolumn{3}{|c|}{ Impact on real imports(\%) } \\
\hline & impact & 4 & 8 & impact & 4 & 8 & impact & 4 & 8 \\
\hline Australia $^{\mathrm{a}}$ & - & - & - & 0,323 & 0,413 & 0,461 & $-0,092$ & $-0,207$ & $-0,218$ \\
\hline Brazil & $-0,049$ & $-0,368$ & $-0,384$ & $-1,264$ & $-1,972$ & $-2,374$ & $-0,252$ & $-0,986$ & $-1,232$ \\
\hline Canada & $-0,106$ & $-0,564$ & $-0,799$ & 0,161 & 0,673 & 0,798 & $-0,202$ & $-0,209$ & $-0,162$ \\
\hline China & 0,182 & 0,734 & 1,086 & 0,157 & 2,133 & 2,912 & $-1,249$ & $-2,677$ & $-3,215$ \\
\hline Japan & $-0,214$ & $-0,306$ & $-0,349$ & 0,969 & 2,400 & 2,690 & $-0,059$ & $-0,196$ & $-0,222$ \\
\hline Korea $^{a}$ & $-0,063$ & $-0,171$ & $-0,064$ & - & - & - & $-0,522$ & $-0,773$ & $-0,452$ \\
\hline Mexico & $-0,231$ & $-0,575$ & $-0,611$ & $-0,319$ & $-1,580$ & $-1,552$ & $-0,124$ & $-0,221$ & $-0,082$ \\
\hline Norway $^{a}$ & 0,032 & $-0,124$ & $-0,146$ & - & - & - & $-0,023$ & $-0,029$ & $\mathbf{0 , 0 8 3}$ \\
\hline New Zealand & $-0,152$ & $-0,268$ & $-0,315$ & $-0,167$ & $-0,327$ & $-0,376$ & $-0,156$ & $-0,159$ & $-0,166$ \\
\hline Singapore & $-0,127$ & $-0,328$ & $-0,387$ & $-2,125$ & $-2,815$ & $-3,142$ & $-0,049$ & $-0,737$ & $-0,926$ \\
\hline Sweden & $-0,129$ & $-0,382$ & $-0,446$ & 0,168 & 0,765 & 0,916 & $-0,192$ & $-0,063$ & $-0,038$ \\
\hline Switzerland & $-0,012$ & $-0,185$ & $-0,206$ & $-0,126$ & $-0,671$ & $-0,864$ & $-0,170$ & $-0,125$ & $-0,133$ \\
\hline United Kingdom & $-0,168$ & $-0,194$ & $-0,209$ & 0,474 & 0,673 & 0,829 & $-0,093$ & $-0,039$ & $-0,060$ \\
\hline United States & 0,166 & 0,163 & 0,160 & $-0,290$ & $-0,852$ & $-1,042$ & $-0,170$ & $-0,619$ & $-1,259$ \\
\hline Euro area $^{\mathrm{a}}$ & 0,111 & 0,304 & 0,350 & $-0,025$ & $-0,664$ & $-0,797$ & $-0,138$ & 0,014 & 0,121 \\
\hline
\end{tabular}

${ }^{a}$ GIRF is not signifiant for the bootsraped $95 \%$ interval confidence. Note: Insignificant results are reported in bold. 
Appendix C - GIRF analysis (overvaluation)

Table 4: Generalized Impulse responses of a positive one standard error shock to U.S. dollar overvaluation

\begin{tabular}{|c|c|c|c|c|c|c|c|c|c|}
\hline & \multicolumn{3}{|c|}{ Impact on real gdp(\%) } & \multicolumn{3}{|c|}{ Impact on exports(\%) } & \multicolumn{3}{|c|}{ Impact on real imports(\%) } \\
\hline & impact & 4 & 8 & impact & 4 & 8 & impact & 4 & 8 \\
\hline Australia $^{\mathrm{a}}$ & 0,073 & 0,087 & 0,097 & - & - & - & $-0,077$ & $-0,510$ & $-0,639$ \\
\hline Brazil & 0,078 & 0,172 & 0,243 & 0,086 & 0,363 & 0,862 & 0,171 & 1,203 & 2,125 \\
\hline Canada & $-0,046$ & $\mathbf{0 , 0 0 9}$ & $\mathbf{0 , 0 3 5}$ & 0,104 & 0,262 & 0,320 & $-0,215$ & $-0,163$ & $\mathbf{0 , 0 1 5}$ \\
\hline China & 0,134 & 0,161 & 0,170 & 0,032 & 0,393 & 0,785 & $-0,428$ & $-1,836$ & $-2,271$ \\
\hline Japan & $-0,043$ & 0,063 & 0,095 & $-0,246$ & 0,509 & $\mathbf{0 , 7 4 5}$ & 0,210 & 0,598 & 1,050 \\
\hline Korea & $-0,141$ & $\mathbf{0 , 0 2 5}$ & 0,049 & $-0,245$ & $-0,037$ & $-0,020$ & $-0,040$ & $\mathbf{0 , 0 7 8}$ & 0,257 \\
\hline Mexico & $-0,076$ & 0,012 & 0,066 & 0,066 & 0,610 & 0,803 & 0,599 & 0,881 & 0,894 \\
\hline Norway $^{\mathrm{a}}$ & $-0,045$ & 0,048 & $\mathbf{0 , 0 7 9}$ & 0,046 & 0,055 & 0,095 & - & - & - \\
\hline New Zealand ${ }^{\mathrm{a}}$ & $-0,029$ & $\mathbf{0 , 0 2 2}$ & $\mathbf{0 , 0 4 7}$ & 0,085 & 0,185 & 0,165 & - & - & - \\
\hline Singapore $^{\mathrm{a}}$ & - & - & - & $-0,527$ & $-0,040$ & 0,304 & $-0,112$ & $-0,131$ & $\mathbf{0 , 0 5 7}$ \\
\hline Sweden & $-0,080$ & 0,048 & 0,103 & $-0,333$ & $-0,119$ & $-0,060$ & 0,137 & 0,268 & 0,402 \\
\hline Switzerland & 0,045 & 0,065 & 0,080 & 0,069 & 0,215 & 0,305 & $-0,105$ & $-0,027$ & 0,119 \\
\hline United Kingdom & $-0,070$ & $-0,100$ & $-0,116$ & $-0,084$ & $-0,277$ & $-0,361$ & 0,037 & 0,240 & 0,445 \\
\hline United States & $-0,224$ & $-0,329$ & $-0,388$ & 0,350 & 0,564 & 0,545 & $-0,010$ & 0,180 & 0,763 \\
\hline Euro area & $-0,105$ & $-0,125$ & $-0,140$ & 0,248 & 0,995 & 1,390 & 0,085 & 0,259 & 0,445 \\
\hline
\end{tabular}

${ }^{a}$ GIRF is not signifiant for the bootsraped $95 \%$ interval confidence.

Note: Insignificant results are reported in bold.

Table 5: Generalized Impulse responses of a positive one standard error shock to euro overvaluation

\begin{tabular}{|c|c|c|c|c|c|c|c|c|c|}
\hline & \multicolumn{3}{|c|}{ Impact on real gdp(\%) } & \multicolumn{3}{|c|}{ Impact on exports(\%) } & \multicolumn{3}{|c|}{ Impact on real imports(\%) } \\
\hline & impact & 4 & 8 & impact & 4 & 8 & impact & 4 & 8 \\
\hline Australia $^{\mathrm{a}}$ & 0,082 & 0,018 & $-0,003$ & $-0,191$ & $-0,233$ & -0.263 & - & - & - \\
\hline Brazil & $-0,045$ & $-0,175$ & $-0,263$ & 0,177 & 0,498 & 0.680 & $-0,358$ & $-1,032$ & $-1,103$ \\
\hline Canada & 0,025 & 0,053 & 0,075 & $-0,031$ & $-0,134$ & -0.158 & $-0,072$ & $-0,563$ & $-0,810$ \\
\hline China $^{\mathrm{a}}$ & 0,075 & 0,115 & 0,127 & 0,152 & 0,637 & -0.793 & - & - & - \\
\hline Japan & $-0,032$ & $-0,065$ & $-0,085$ & $-0,094$ & $-0,455$ & -0.520 & $-0,135$ & $-0,509$ & $-0,744$ \\
\hline Korea & $-0,051$ & $-0,339$ & $-0,359$ & $-0,091$ & $-0,166$ & -0.163 & $-0,397$ & $-1,064$ & $-1,303$ \\
\hline Mexico & $-0,071$ & $-0,085$ & $-0,086$ & $-0,023$ & $-0,061$ & -0.072 & $-0,205$ & $-0,920$ & $-1,314$ \\
\hline Norway & $-0,114$ & $-0,135$ & $-0,158$ & $-0,415$ & $-0,380$ & -0.397 & $-0,019$ & $-0,233$ & $-0,344$ \\
\hline New Zealand ${ }^{\mathrm{a}}$ & $-0,022$ & $-0,084$ & $-0,110$ & - & - & - & - & - & - \\
\hline Singapore & $-0,132$ & $-0,162$ & $-0,180$ & $-0,077$ & $-0,435$ & -0.494 & 0,503 & $-0,092$ & $-0,382$ \\
\hline Sweden & 0,143 & $-0,003$ & $-0,054$ & 0,791 & 0,051 & -0.104 & 0,477 & 0,147 & $-0,195$ \\
\hline Switzerland $^{\mathrm{a}}$ & 0,084 & 0,016 & $-0,008$ & $-0,135$ & $-0,284$ & -0.311 & - & - & - \\
\hline United Kingdom & 0,032 & $-0,066$ & $-0,105$ & $-0,103$ & $-0,225$ & -0.280 & $-0,215$ & $-0,333$ & $-0,578$ \\
\hline United States & $-0,041$ & $-0,087$ & $-0,108$ & $-0,096$ & $-0,169$ & -0.154 & 0,013 & $-0,389$ & $-0,620$ \\
\hline Euro area & $-0,085$ & $-0,179$ & $-0,216$ & $-0,280$ & $-0,412$ & -0.381 & 0,664 & 1,149 & 1,473 \\
\hline
\end{tabular}

${ }^{a}$ GIRF is not signifiant for the bootsraped $95 \%$ interval confidence.

Note: Insignificant results are reported in bold. 
Table 6: Generalized Impulse responses of a positive one standard error shock to China overvaluation

\begin{tabular}{|c|c|c|c|c|c|c|c|c|c|}
\hline & \multicolumn{3}{|c|}{ Impact on real gdp(\%) } & \multicolumn{3}{|c|}{ Impact on exports(\%) } & \multicolumn{3}{|c|}{ Impact on real imports(\%) } \\
\hline & impact & 4 & 8 & impact & 4 & 8 & impact & 4 & 8 \\
\hline Australia & 0,082 & 0,188 & 0,267 & 0,041 & 0,066 & 0,083 & 0.132 & 0.396 & 0.684 \\
\hline Brazil & 0,018 & 0,302 & 0,603 & 0,542 & 2,468 & 3,849 & 0.192 & 1.146 & 3.045 \\
\hline Canada & 0,104 & 0,187 & 0,238 & 0,245 & 0,510 & 0,814 & 0.030 & 0.192 & 1.146 \\
\hline China & $-0,414$ & $-0,489$ & $-0,485$ & $-0,034$ & $-0,044$ & $-0,048$ & $-0,737$ & 1.952 & 5.041 \\
\hline Japan $^{\mathrm{a}}$ & $-0,137$ & $\mathbf{0 , 0 2 0}$ & 0,176 & 0,621 & 1,888 & 2,784 & 0.026 & -0.034 & -0.108 \\
\hline Korea $^{\mathrm{a}}$ & - & - & - & 0,347 & 0,514 & 0,517 & -0.244 & -1.343 & -1.630 \\
\hline Mexico & 0,065 & 0,389 & 0,600 & 0,246 & 1,434 & 2,457 & 0.150 & 0.859 & 1.571 \\
\hline Norway $^{\mathrm{a}}$ & $-0,062$ & 0,086 & 0,205 & 0,034 & 0,131 & 0,192 & - & - & - \\
\hline New Zealand & 0,055 & 0,189 & 0,292 & 0,052 & 0,260 & 0,341 & - & - & - \\
\hline Singapore & 0,131 & 0,424 & 0,620 & 0,256 & 2,103 & 3,609 & - & - & - \\
\hline Sweden & 0,019 & 0,245 & 0,442 & 0,127 & 0,455 & 0,693 & - & - & - \\
\hline Switzerland & 0,067 & 0,184 & 0,266 & 0,089 & 0,568 & 0,929 & - & - & - \\
\hline United Kingdom & 0,056 & 0,120 & 0,155 & 0,019 & 0,594 & 1,044 & 0,019 & 0.153 & 0.276 \\
\hline United States & 0,051 & 0,168 & 0,229 & 0,123 & 0,645 & 0,870 & -0.063 & -0.271 & -0.579 \\
\hline Euro area & $-0,135$ & $-0,288$ & $-0,399$ & 0,214 & 0,966 & 1,632 & 0,158 & 0,406 & 0,591 \\
\hline
\end{tabular}

${ }^{a}$ GIRF is not signifiant for the bootsraped $95 \%$ interval confidence.

Note: Insignificant results are reported in bold.

\section{Appendix D - Generalized forecast error variance}

Table 7: Generalized forecast error variance decomposition GDP growth: undervaluation case

\begin{tabular}{|c|c|c|c|c|c|c|c|c|c|c|}
\hline & & \multicolumn{3}{|c|}{ United States } & \multicolumn{3}{|c|}{ China } & \multicolumn{3}{|c|}{ Euro Zone } \\
\hline & & 0 & 4 & 8 & 0 & 4 & 8 & 0 & 4 & 8 \\
\hline Australia & $\mathrm{y}$ & 13,39 & 15,78 & 16,87 & 4.08 & 4.04 & 3.50 & 6,43 & 7,63 & 8,78 \\
\hline Brazil & $\mathrm{y}$ & 4,21 & 5,16 & 6,10 & 4.37 & 10,24 & 12,48 & 2,76 & 3,49 & 4,24 \\
\hline Canada & $\mathrm{y}$ & 23,83 & 26,39 & 28,65 & 1.80 & 1.16 & 0.56 & 21,41 & 33,32 & 38,60 \\
\hline China & $\mathrm{y}$ & 24,58 & 26,10 & 27,18 & 46.77 & 56,52 & 53.26 & 25,16 & 18,33 & 17,28 \\
\hline Japan & $\mathrm{y}$ & 25,60 & 33,23 & 30,89 & 24.76 & 22.61 & 18.93 & 10,13 & 8,61 & 8,61 \\
\hline Korea & $\mathrm{y}$ & 13,07 & 14,49 & 15,78 & 14.02 & 17.36 & 19.60 & 3,20 & 4,75 & 6,47 \\
\hline Mexico & $\mathrm{y}$ & 8,67 & 7,43 & & 5.23 & 9.51 & & 7,51 & 6,71 & 5,97 \\
\hline Norw & $\mathrm{y}$ & 8,48 & 10,84 & 9,34 & 3,92 & 1.42 & 1.42 & 24,40 & 24,31 & 24,19 \\
\hline & $\mathrm{y}$ & 11,60 & 10,56 & 10,29 & 4.05 & 2.41 & & 5,24 & 5,12 & 5,15 \\
\hline Singapore & $\mathrm{y}$ & 9,39 & 14,07 & 9,33 & 20.42 & 22,09 & 22.98 & 25,74 & 32,98 & 29,18 \\
\hline & $\mathrm{y}$ & 7,30 & & & 7.65 & 1.53 & & 32,16 & 31,22 & 31,12 \\
\hline Switzerland & $\mathrm{y}$ & 3,72 & 10,79 & 10,15 & 6.40 & 7.41 & 7.79 & 11,77 & 13,94 & 13,08 \\
\hline United Kingdom & $\mathrm{y}$ & 39,67 & 40,61 & 31,98 & 13.91 & 26.13 & 17.13 & 35,84 & 35,19 & 34,85 \\
\hline United States & $\mathrm{y}$ & 44,34 & 47,46 & 49,98 & 17.19 & 14.32 & 12.79 & 39,35 & 34,68 & 30,41 \\
\hline Euro area & $\mathrm{y}$ & 49,94 & 44,78 & 40,41 & 14.09 & 15.39 & 16.27 & 39,07 & 35,11 & 31,60 \\
\hline
\end{tabular}


Table 8: Generalized forecast error variance decomposition on GDP growth: overvaluation case

\begin{tabular}{|c|c|c|c|c|c|c|c|c|c|c|}
\hline & & \multicolumn{3}{|c|}{ United States } & \multicolumn{3}{|c|}{ China } & \multicolumn{3}{|c|}{ Euro Zone } \\
\hline & & 0 & 4 & 8 & 0 & 4 & 8 & 0 & 4 & 8 \\
\hline Australia & $\mathrm{y}$ & 16,28 & 16,99 & 11,06 & 13,81 & 12,87 & 15,02 & 20,26 & 22,90 & 23,31 \\
\hline Brazil & $\mathrm{y}$ & 19,99 & 39,19 & 52,10 & 15,46 & 17,26 & 17,03 & 22,75 & 23,07 & 22,72 \\
\hline Canada & $\mathrm{y}$ & 24,71 & 21,56 & 23,52 & 8,86 & 18,21 & 28,26 & 41,83 & 15,91 & 9,19 \\
\hline China & $\mathrm{y}$ & 43,72 & 49,68 & 53,20 & 53,08 & 56,34 & 69,24 & 27,10 & 40,06 & 28,78 \\
\hline Japan & $\mathrm{y}$ & 26,88 & 27,19 & 27,39 & 22,69 & 23,03 & 23,28 & 14,10 & 54,83 & 52,99 \\
\hline Korea & $\mathrm{y}$ & 35,91 & 43,41 & 42,90 & 25,84 & 21,15 & 20,42 & 20,72 & 20,63 & 20,40 \\
\hline Mexi & $\mathrm{y}$ & 35,63 & & 40,37 & 16,87 & 11,79 & 10,89 & 26,04 & 41,49 & 43,08 \\
\hline & $\mathrm{y}$ & 2,01 & & 2,15 & 3,75 & 11,18 & 16,32 & 20,78 & 13,16 & 13,89 \\
\hline New Zealand & $\mathrm{y}$ & 19,49 & 64,01 & 63,88 & 19,07 & 17,46 & 25,18 & 31,60 & 38,74 & 43,10 \\
\hline Singapore & $\mathrm{y}$ & 35,36 & 33,65 & & 14,67 & 29,72 & 36,55 & 22,40 & 35,32 & 56,10 \\
\hline Sweden & $\mathrm{y}$ & 6,00 & 5,74 & 5,47 & 8,23 & 4,41 & 4,04 & 41,98 & 41,59 & 40,09 \\
\hline Switzerland & $\mathrm{y}$ & 19,60 & 13,96 & & 3,31 & 13,71 & 19,87 & 23,71 & 30,22 & 32,29 \\
\hline United Kingdom & $\mathrm{y}$ & 45,53 & 25,34 & 12,30 & 12,89 & 13,35 & 29,11 & 36,94 & 39,49 & 39,55 \\
\hline United States & $\mathrm{y}$ & & & & 20,97 & 35,22 & & 55,46 & 56,43 & 54,27 \\
\hline Euro area & $\mathrm{y}$ & 42,87 & 32,36 & 27,39 & 27,33 & 37,18 & 42,88 & 48,08 & 49,83 & 51,08 \\
\hline
\end{tabular}

